Article

\title{
The City of the Future
}

\author{
Garry Glazebrook ${ }^{1, *}$ and Peter Newman ${ }^{2}$ \\ ${ }^{1}$ Department of Design, Architecture and Building, University of Technology Sydney, Ultimo, NSW 2007, Australia; E-Mail: \\ garry.glazebrook@uts.edu.au \\ ${ }^{2}$ Curtin University Sustainability Policy Institute (CUSP), Perth, WA 6845, Australia; E-Mail: p.newman@curtin.edu.au \\ * Corresponding author
}

Submitted: 31 October 2017 | Accepted: 5 March 2018 | Published: 24 April 2018

\begin{abstract}
Limiting global warming to $1.5^{\circ} \mathrm{C}$ will require rapid decarbonisation of the world's electricity and transport systems. This must occur against a background of continuing urbanisation and the shift to the information economy. While replacement of fossil fuels in electricity generation is underway, urban transport is currently dominated by petrol and diesel-powered vehicles. The City of the Future will need to be built around a different transport and urban paradigm. This article argues that the new model will be a polycentric city linked by fast electric rail, with local access based on autonomous "community"owned electric cars and buses supplemented by bicycles, electric bikes and scooters, with all electricity generated from renewables. Less space will be wasted on roads and parking, enabling higher accessibility yet more usable public open space. Building the cities of the future will require national governments to accelerate local initiatives through appropriate policy settings and strategic investment. The precise way in which individual cities move into the future will vary, and the article illustrates how the transformation could work for Australian cities, like Sydney, currently some of the most car dependent in the world, using new financial and city partnerships.
\end{abstract}

\section{Keywords}

$1.5^{\circ} \mathrm{C}$ agenda; decarbonisation; future city; information and communication technology; public space; transport

\section{Issue}

This article is part of the issue "Urban Planning to Enable a $1.5^{\circ} \mathrm{C}$ Scenario", edited by Peter Newman (Curtin University, Australia), Aromar Revi (Indian Institute for Human Settlements, India) and Amir Bazaz (Indian Institute for Human Settlements, India).

(C) 2018 by the authors; licensee Cogitatio (Lisbon, Portugal). This article is licensed under a Creative Commons Attribution 4.0 International License (CC BY).

\section{Introduction}

With more than $50 \%$ of the world's population living in cities, and urban areas now accounting for more than $70 \%$ of global $\mathrm{CO} 2$ emissions and creating more than $80 \%$ of the world's GDP, solutions to global warming will inevitably involve cities reducing their greenhouse "footprints" (IPCC, 2014a). This will apply both to the long-established cities and to the rapidly expanding cities such as in Asia, the Middle East and Africa (Moriarty \& Honnery, 2013). A key component of this will be reduced $\mathrm{CO} 2$ emissions from urban transport, which is currently dominated by private cars using fossil fuels. This will require a transformation of our transport sector away from so much reliance on cars and away from reliance on oil towards electrically powered vehicles and systems, powered by renewable energy (Newman, Beatley, \& Boyer, 2017).

The timescale for this transformation is very short. Indications from the IPCC AR5 Report (IPCC, 2014a) are that we have at best four decades to substantially reduce greenhouse emissions from all sources. The IPCC $1.5^{\circ} \mathrm{C}$ agenda is now suggesting we will need an even faster transition. This article is attempting to overview how cities will need to manage this transition to the City of the Future which features the removal of all fossil fuels in the passenger transport arena.

The move to renewable energy in the generation of electricity is now underway in earnest (Newman, 2017a), and there are indications that global coal consumption 
has peaked and started to decline (IEA, 2017a). In contrast, emissions from the transport sector and use of oilbased fuels continues to rise though at a reduced rate at a global level and in many cities and nations it is now decoupling from economic growth (Newman, 2017b).

There are a number of indications that trends in the transport sector are beginning to change:

- Per-capita car usage in many cities and countries is now falling, and there is a growing trend to reduced car dependent urban forms with a growth in transit and active transport modes, which have much lower emissions per passenger-kilometre (Goodwin \& van Dender, 2013; Mittal, Dai, \& Shukla, 2016; Newman \& Kenworthy, 2015);

- Electric cars are beginning to gain market share and are poised to replace petrol and dieselpowered cars over the coming decades. Provided their electric energy is derived from renewables, this promises a substantial reduction in emissions (IEA, 2016);

- Self-drive or autonomous vehicle technology is also emerging rapidly. This provides an option to re-think the current paradigm of urban transport, which is based on privately owned automobiles and which has grown to dominate most of the world's cities, especially since 1950 (Carlin, Rader, \& Rucks, 2015). However as discussed later, unthinking application of autonomous vehicle technology to simply replace current vehicles on a onefor-one basis will not produce significant benefits except in the area of safety.

This article looks at how these emerging trends could combine to generate a radical transformation not only of transport technologies and travel behaviour, but of the way we build and live in our cities. It suggests that the growing need for urban accessibility can be solved by a combination of:

- The emergence of a poly-nucleated urban form, combining a strong city centre with strong subcentres, allowing accessibility to be maximised but travel minimised;

- Increased investment in high capacity electric rail transport links for trips to urban centres and for longer distance travel in urban areas, with a concomitant reduction in investment in general purpose roads and freeways;

- The large-scale replacement of private automobiles by jointly-owned and operated self-drive vehicles, which combined with bicycles and small scale electric scooters and cycles could cater for dispersed travel as well as feeder trips to centres and public transport nodes.

The article examines how these trends could emerge, their potential benefits, and how they could be encour- aged by appropriate policies at national, state and local level. It then looks in detail at how they could apply in Australian cities using Sydney as a case study; currently Australian cities are amongst the most car-dependent and transport emissions intensive in the world and they are also experiencing rapid population growth which enables them to demonstrate rapid transformation.

The article looks at the history of urban transport and how it is now changing suggesting a new urban paradigm is emerging; these trends are used to create what could be The City of the Future and how it can be imagined to help with the $1.5^{\circ} \mathrm{C}$ agenda.

\section{Brief History of Urban Transport}

Whilst there have been many changes in technology in the last few centuries, especially in fields such as information technology, medicine or manufacturing, it is a curious fact that the technologies which currently dominate urban transport are all essentially products of the 19th century-the tram, train and especially the car (Newman, Kosonen, \& Kenworthy, 2016). Whilst modern versions of these modes are more developed in many ways such as safety and comfort, they are little changed in the key characteristics (capacity, effective speed), which determine how they accommodate urban travel and also how they shape our cities (Newman \& Kenworthy, 2015, 1999).

In contrast, all of these modes represented a major leap forward over previous transport technologies (walking, horse drawn vehicles) when they were first introduced. Indeed, in many respects our current transport systems have gone backwards in recent years. Cars and freeways which can only handle around 3,000 passengers per lane per hour have come to dominate longer distance travel over rail-based solutions, which can handle ten times that movement in the same space. Meanwhile the very success of the car has led to rising traffic congestion, and with it slower speeds, both for the cars themselves and for any other vehicles (trucks, buses, trams, bicycles) caught up in the congestion. Thus urban efficiency as a whole has declined, notwithstanding the apparent improvement in personal mobility.

\subsection{The First Rail Age}

Prior to the industrial revolution, most urban travel was by foot, with typical walking speeds of 3-4 km/hr. The rich could afford horse-drawn travel options, allowing those speeds to be tripled. Bicycles also for a time provided quite an increase in personal mobility. But it was the train and the electric tram which first revolutionised urban travel, and they transformed cities from Europe to America to Australia in the late 19th century.

The radical increase in speed made possible by these modes, combined with their high capacity, meant that public transport came to dominate urban travel patterns in many major cities around the world within a 
few decades. While every city has its own unique history, geography, topography and urban economy, these technologies were applied almost universally in mediumsized or larger cities, and tended to have similar impacts. "New World" cities were much younger and in most cases smaller and lower density than their European counterparts when these technologies arrived. Nevertheless, electric trams (and electric inter-urbans) became commonplace across the new cities of North America and Australia. Sydney developed one of the world's largest and most heavily used tram networks, as well as a substantial suburban electric rail network by the 1930s, despite having only a few thousand inhabitants when the technologies were first invented. Similarly, more populous cities like Paris, Berlin and New York all introduced underground electric metro systems in the decades following the introduction of the first such system in London.

The railways in particular allowed cities to expand rapidly in their geographical areas. In European cities, this sometimes meant leaping across the old walls within which they had been confined for centuries. In other cases, long tentacles of development followed the railways out into the countryside, with the rich escaping the pollution and crime in the inner cities and commuting into the city for work or business. This was the precursor to the widespread "dormitory" suburbs which spread rapidly (but in all directions) with the rise of the car and freeway after 1950. In all these cities the 19th century rail innovations and urban development went hand-in-hand and were created by entrepreneurs who established partnerships with city governments (Newman, Davies-Slate, \& Jones, 2017).

Another impact of the first rail age was on city centres. The ability to bring large numbers of people to the centre reinforced the parallel development of the skyscraper in those cities which did not have height limits. Chicago is perhaps the quintessential example, often seen as the home of the skyscraper, but also the biggest rail hub in the US and the fastest growing city in the world in the late 19th century.

In cities like London, Paris or Tokyo which were already densely settled over a large area before the first rail age, networks of rail lines covered a large part of the inner urban area, and the city centre was more spread-out. This was reinforced by height limits (in the case of Tokyo because of earthquake risk). These cities tended to have a number of privately owned rail systems, mostly built on the surface, each with their own city terminus. These in turn were connected by underground or metro systems, like London's "Circle Line".

At the metropolitan scale, most rail systems resembled radial networks. A few cities however, such as Berlin or Moscow, developed "ring metros" to complement their radial networks. The inner urban areas were often criss-crossed with metro and/or light rail networks.

While the development of cities in the first rail age is well understood, the key aspects to focus on here are that:
- The basic transport technologies spread very rapidly around the world;

- Each city utilised the technologies somewhat differently, based on their previous history, geography, economy and culture;

- Rail systems both spread housing development along the rail corridors and reinforced a range of urban centres, particularly the Central Business District, for commerce;

- The high capacity of rail systems allowed them to dominate urban travel (measured in passengerkilometres) and to allow those cities which had strong economies to expand rapidly in population;

- The predominance of urban public transport was an equalising force in society once fares dropped to the levels affordable by the working class, increasing accessibility and allowing people to travel further. This in turn facilitated increasing specialization of the workforce.

\subsection{The Car and Freeway Age}

The first half of the 20th century saw the consolidation of the first rail age but also the rise of the automobile age, especially in the US where mass-produced cars allowed ownership to spread rapidly. The Depression and two World Wars slowed the process, but the car age started in earnest after 1950. The car offered two-dimensional, door-to-door flexibility, which quickly made trams that shared road space with cars, obsolete. Rail-based systems, however, were more resilient, having higher speeds and their own rights of way. A few cities retained their trams and and have since built on them as a major feature of their economic and social life (see Figure 1).

As car ownership and use expanded, land uses began to react. The car allowed low density suburbs to fill in the gaps between the rail corridors, but also reduced the primacy of the traditional city centre in terms of accessibility. Employment and other services found cheaper land in the suburbs and a general process of decentralisation began. Shops and other activities did coalesce into retail malls and office and industrial parks but in many cities these were surrounded by car parks and inaccessible by good quality public transport. Buses replaced trams in many cities but failed to halt the decline of public transport and in many cases exacerbated it. However, the rapid rise in cars produced a massive rise in road congestion, especially for cities with over one million inhabitants. The answer for a while appeared to be the urban motorway. US cities took this furthest, building on the Interstate Highway system, but many other cities from Seoul to Singapore to Sydney built networks of elevated or in some cases underground roads.

As with the first rail age, the responses by individual cities to the car differed. Most cities embraced the idea of the motorway, and their building programs were only limited by the availability of resources. In some cities 


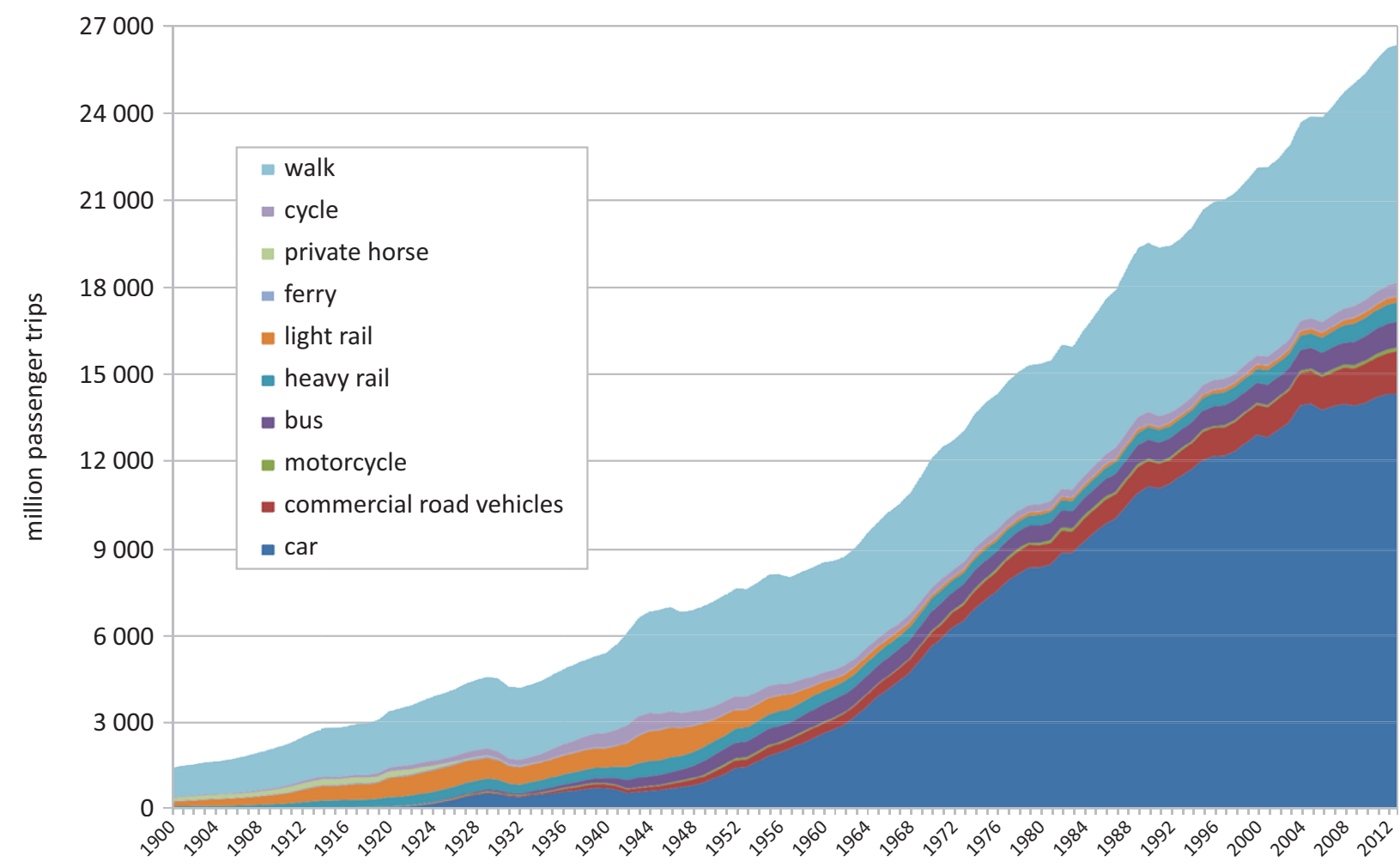

Figure 1. Metropolitan passenger trips in australia's capital cities, 1900-2013. Source: Bureau of Infrastructure Transport and Regional Economics (BITRE, 2014). Notes: Includes total annual passenger tips (for years ending 30 June) within all State and Territory capital cities, across all available transport modes (including rough estimates of non-motorised travel). Values for 'light rail' include estimates for the Sydney Monorail (as well as for early horse-drawn or steam trams). Values for 'bus' cover: all motor vehicles with 10 or more seats (i.e. charter/hire buses and other private buses/minibuses, in addition to UPT route buses), including the use of trolley-buses; as well as horse-drawn buses for early years. Values for 'private horse' include carriage and saddle horses, but not those used for horse-buses and horse-trams-which are included in the relevant mass transit modes. Values for 'commercial road vehicles' related to non-freight use of such vehicles (primarily due to travel by light commercial vehicles such as utilities and panel vans).

however, there was strong opposition to motorways from environmentalists, the public or from affected residents in the path of the freeways (Bratzel, 1999; Stone, 2014). In Sydney for example a series of protest movements involving unions, residents and others managed to halt inner city freeway development for twenty years. When it finally returned, it was in the form of largely underground toll-ways.

By 2000, cities in the developed world were firmly car-dominated, with a few exceptions such as Tokyo, which had high densities and the world's most heavily utilised urban rail system. Figure 1 (BITRE, 2014) shows, for example, the trends in trips by different modes in Australian capital cities, from 1900 to 2012. In the developing world, car ownership was not yet within the reach of the public, but was still seen as aspirational.

Nevertheless, there are significant differences between cities, even within the same country or with similar income levels, as to their reliance on different transport modes or their urban form. Singapore for example has far lower car use and far higher public transport use per capita than US cities with similar or lower income levels. Sydney has significantly less car use than other Aus- tralian cities; New York is completely different to the rest of the US, accounting for a massive $60 \%$ of all heavy rail use across the entire country. History, geography, politics and other factors can make a difference.

\subsection{The Second Rail Age}

A major change began to occur however around the turn of the 20th century which has been called "the second rail age" (Newman, Glazebrook, \& Kenworthy, 2013). Per-capita car usage, which had climbed inexorably for fifty years, began to decline in some places. By 2005, the trend was becoming more widespread-after that year for example, all Australian capital cities began to experience the "peak car" phenomenon (Newman \& Kenworthy, 2015). The phenomenon has now been demonstrated in China (Gao \& Newman, 2018).

The cities began to change their priorities with urban regeneration growing faster than urban sprawl and a strong reaction to the building of freeways. These protests have grown in more recent years with 22 cities now removing freeways and major political shifts in cities being created around the need to change priorities away 
from high capacity roads (Gaynor, Newman, \& Jennings, 2017; Newman \& Kenworthy, 2015).

About the same time, public transport, which had in many cities been static or in decline for decades, began to rise rapidly. And City, Regional and National Governments have begun changing their investment strategies:

- In the US for example, there are now some 28 light rail systems in place, most built since 2000 . Ridership on all forms of urban rail transport (heavy rail, commuter rail and light rail) has risen much more rapidly than population, although bus ridership has stalled or fallen in the last two decades (See Figure 2);

- In Europe, light rail has also made a revival, particularly in countries such as France and Spain, while major new underground rail systems have been built or are under construction in many older cities from Athens to Paris to London. See Figure 2 on UK rail growth;

- Rail, including automated metros, is in fact expanding rapidly around the world, but most notably in Asia, and in particular China, where 52 cities have built metro systems and some light rail systems. Major rail systems are now being built in Latin America, the Middle East, Africa and Australasia as well. Rail passenger kms have grown $46 \%$ between 2002 and 2015 when they had plateaued or declined for most of the previous 5 decades; high speed rail has grown over 6 times (IEA \& UIC, 2016);

- Sydney is currently investing $\$ 40$ billion in transport infrastructure, half on metro and light rail systems and half on a massive Toll-way system called
West Connex. But the travel data points the way: last year there was a $11 \%$ increase in patronage on the rail network, while car usage is growing at only around $2 \%$ pa or in per capita terms it is in decline;

- 22 cities such as Seoul and San Francisco have actually removed urban freeways (the latter following an earthquake) and Paris is now closing some motorways along the Seine. Road pricing has also been introduced in cities like London, Oslo, Singapore and Stockholm (Newman \& Kenworthy, 2015).

Illustrations of the second rail age are provided in Figure 2 (for the UK) and Figure 3 (for the US). In the case of Australia, Figure 4 shows the dominance of the original tram systems up until about 1950, the rapid decline in public transport use (particularly tram usage, as most tram systems were closed) until about 1980, and the recovery in public transport use, particularly on rail, since then.

The reason for this "second rail revolution" appears to be related to the declining speed of traffic and increased speed of urban rail which has been able to go around, over and under the growing traffic problems of cities on every continent (Newman \& Kenworthy, 2015). There are also a range of good public policy reasons for this shift in priorities to electric urban rail.

\subsection{The Urban Form Associated with Transport}

The literature on how transport technologies have shaped cities is extensive (Anas, Arnott, \& Small, 1998; Batty \& Longley, 1994; Frey, 1999; Lynch, 1981; Newman \& Kenworthy, 1989, 1999, 2015). The data show the old walking cities losing density in population and jobs as the

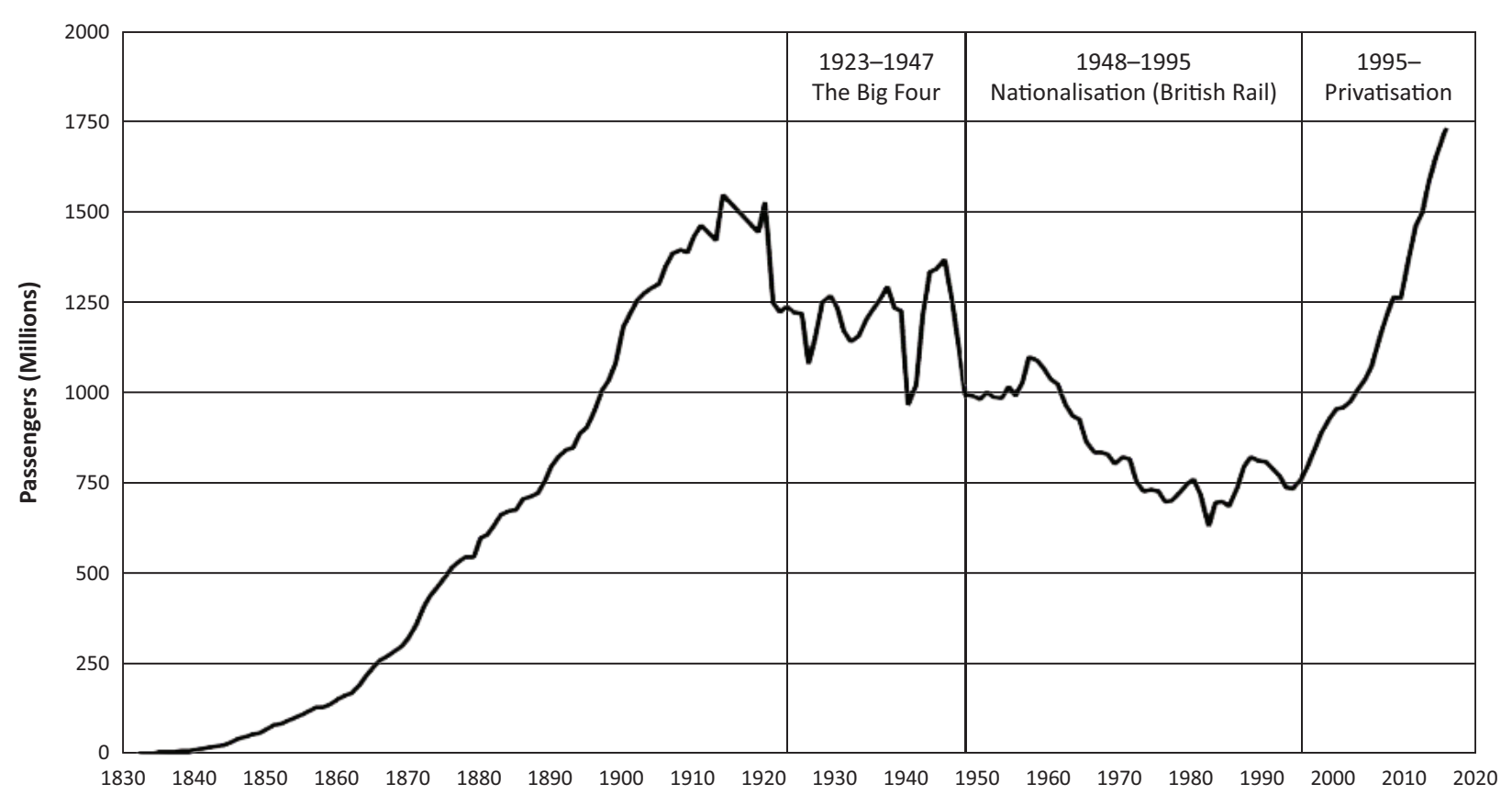

Figure 2. The growth in UK rail showing the first age and now the second age of rail. Source: Data sourced from Association of Train Operating Companies and the Office of Rail Regulation, UK, at Wikimedia Commons (2018). 


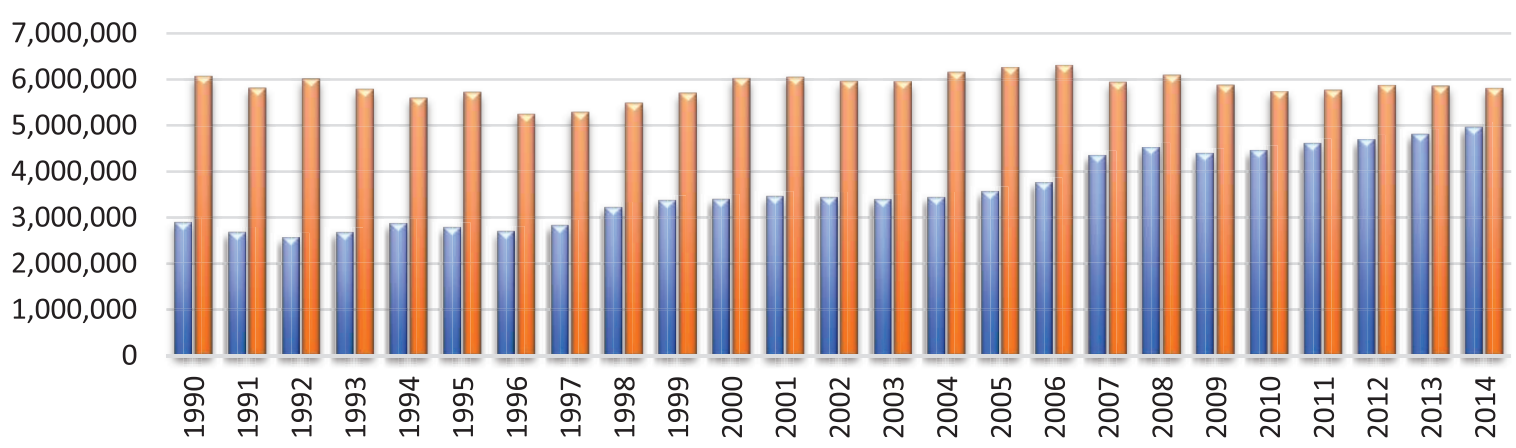

$\square$ Heavy Eail, Commuter Rail and Light Rail $\square$ Bus, Trolleybus, DRT and Other

Figure 3. Rail and bus patronage in the Unites States, 1990-2014. Source: American Public Transport Association (APTA, 2016).

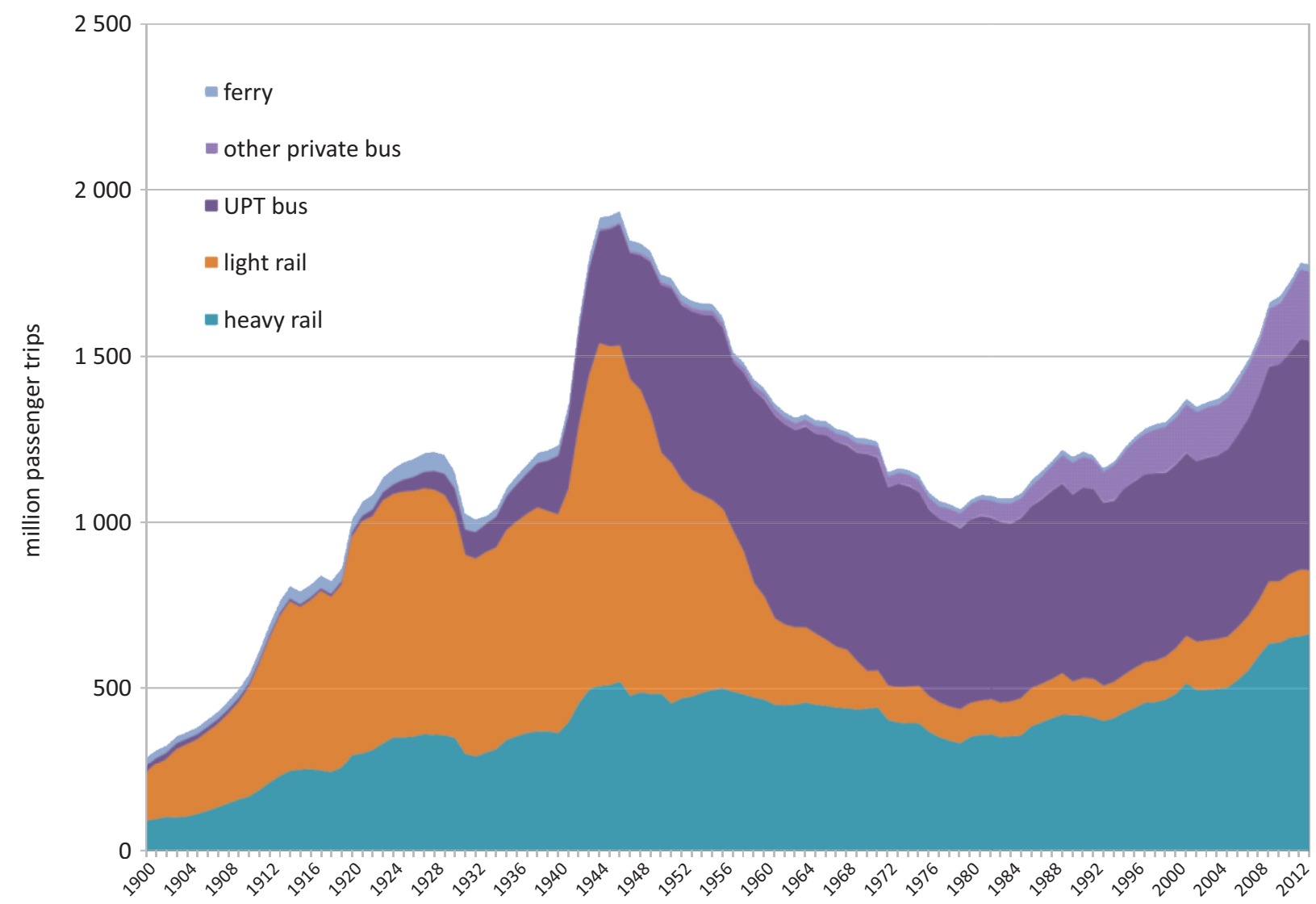

Figure 4. Urban public transport trips in Australian capital cities, 1900-2013. Source: BITRE, 2014. Notes: Includes total annual passenger tips (for years ending 30 June) within all State and Territory capital cities, across all mass transit (including rough estimates of horse-drawn vehicles). Values for 'light rail' include estimates for the Sydney Monorail (as well as for early horse-drawn or steam trams). Values for 'UPT bus' cover all route/school bus services, including the use of trolleybuses and horse-drawn vehicles for early years. Values for 'other private bus' are very approximate allowances for such vehicles, giving the roughly estimated contribution of charter/hire buses (and other non-UPT buses/minibuses).

tram and train spread the city out into a polycentric form, then the density reduced further as cars dispersed the city very rapidly. Now, densities are rising as the polynuclear urban form is again being favoured by renewed priority in rail systems and the increasing value of the old walking city centres with knowledge economy activity (Newman \& Kenworthy, 2015; Matan \& Newman, 2017).

\section{The Climate Challenge}

The IPCC Fifth Assessment Report (IPCC, 2014b) indicates that transport accounted for $14 \%$ of global Greenhouse Gas emissions in 2010, with $95 \%$ of transport energy coming from oil. This compares with $25 \%$ for electricity and heat production, $23 \%$ for agriculture, forestry and 
land use, $18 \%$ for industry, $12 \%$ for other and $8 \%$ for buildings. In fact, the full share attributable to transport would be higher, as some electricity is used for transport and some share of manufacturing is used to build transport vehicles and infrastructure.

Globally there is evidence that coal consumption has begun to decline slightly, after a decade or more of rapid increases. However, oil and gas consumption has been rising for the last five years as a result of the revolution in drilling techniques in the US (IEA, 2017a). See Figure 5.

While renewable energy in electricity generation, especially wind and solar, is now increasing and beginning to displace coal and gas, energy consumption and emissions for transport continue to rise. For urban passenger transport, there are marked differences in energy effi- ciency, and hence emissions, between different modes (Figure 6), with passenger rail over six times more efficient than cars, and buses three times more efficient (IEA, 2017b).

The focus on cities to help shape the response to global warming has been growing, particularly with organizations like C40, ICLEI and 100 Resilient Cities showing that cities must lead this transition to remove fossil fuels (C40, 2017). Many cities are now showing that they can remove fossil fuels much quicker than their national commitments (Kramers et al., 2013; Newman, Beatley, \& Boyer, 2017). In every city which is planning to remove fossil fuels the strategy is to build a renewable electricity system and then electrify the transport system. Such planning builds on a number of emerging trends.

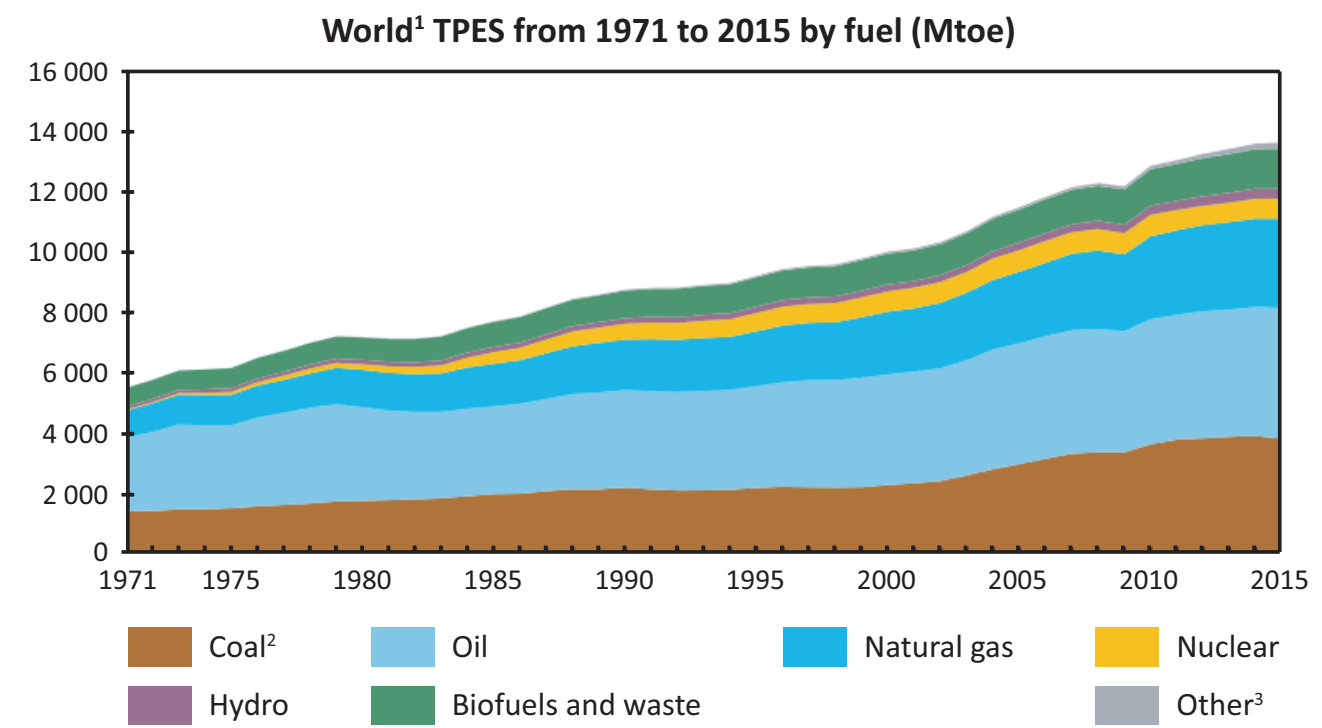

Figure 5. Global fossil fuel consumption. Source: International Energy Agency (IEA, 2017a).

\section{Passenger transport in IEA ${ }^{1}$ : energy per passenger-kilometre (MJ/pkm)}

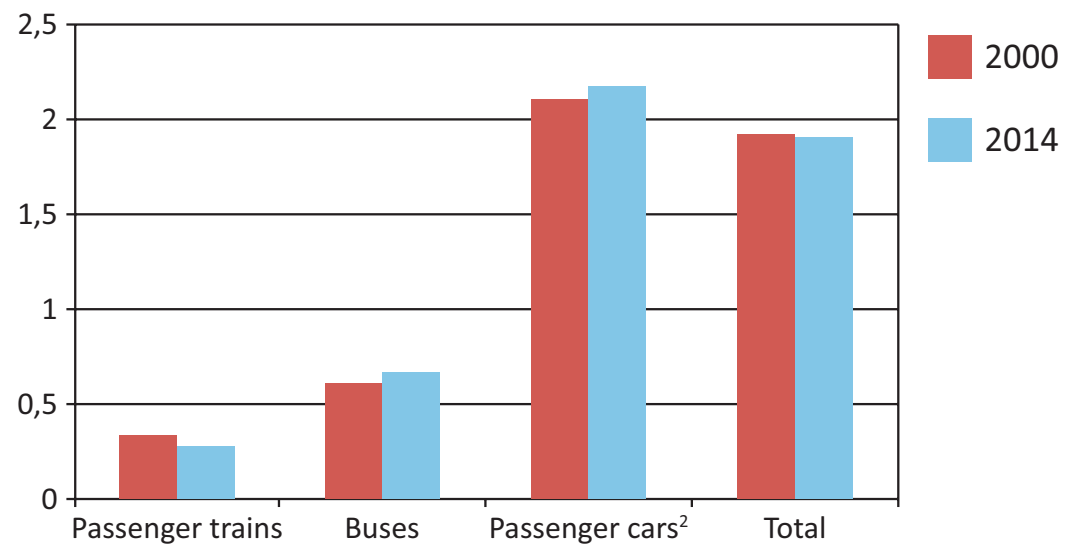

Figure 6. Energy efficiency by mode for passenger transport. Source: International Energy Agency (IEA, 2017b). Notes: 1. Refers to the 19 IEA countries for which data are available for most end-uses: Australia, Austria, Canada, Czech Republic, Finland, France, Germany, Greece, Ireland, Italy, Japan, Korea, New Zealand, the Netherlands, Spain, Sweden, Switzerland, the United Kingdom and the United States. 2. Passenger cars include cars, sport utility vehicles and personal trucks. 


\section{Emerging Trends}

Some of the key emerging trends which will affect how cities and their transport systems evolve in future are outlined below.

\subsection{Peak Car}

As noted earlier, per capita car use is now in decline in many cities and countries, and in a few cities absolute volumes of traffic are also declining. This phenomenon has been identified for some time by academics (Goodwin \& van Dender, 2013; Newman \& Kenworthy, 2011) but is now becoming apparent to mainstream media (Rapier, 2017). Recent research (Sivak, 2017) confirms that vehicle ownership per capita in the US peaked in 2006, and per capita kilometres driven per person peaked in 2004, although both have rebounded slightly since their lows of 2012-13.

The reasons for this are many, and include:

- The declining utility of cars in many urban areas as a result of high levels of traffic congestion and the high costs of parking;

- The trend back to city centres and inner-city areas both for business and for residential use leading to rises in density that favours non-car modes of transport;

- Changes in behaviour, particularly by millenials, many of whom no longer bother to get drivers' licences;

- Improvements in alternatives to the private car, including mass transit, car sharing, improved taxi services such as "Uber" and bike share schemes.

This has occurred despite falling costs for purchasing new vehicles with the entry of competitive firms based in Korea and now China, and relatively low prices for fuel. All these trends were associated with increased use of smart phones and social media which are enabling people to make choices based on simple and rapid communications. As shown below this is likely to continue to grow with smart technology shaping transport and land use systems very directly (Newman, 2016).

\subsection{Electric Vehicles}

Electric cars, trams and trains have been available for over a century, the former using early batteries, and the latter using overhead or third rail systems for providing electrical power.

While electric power for rail based transport became increasingly common in the 20th century, electric cars proved uncompetitive with gasoline powered cars due to the limited energy densities of early lead-acid batteries. However, developments in battery technology and pressures to reduce urban pollution and greenhouse gas emissions is leading to a "second coming" for the electric car. Whilst hybrid and full-electric vehicles only made up about $4 \%$ of world automobile sales in 2016, sales in 2016 grew by $60 \%$ on a year earlier (see Figure 6) and there were an estimated 2 million electric cars on the road by 2016. EV's are beginning to become common where suitable government policies make them attractive-for example in Norway, where high taxes on regular cars and incentives for electric cars saw the latter achieve $30 \%$ of sales of new cars in 2016 .

As sales of electric cars increase (Figure 7), so their costs have begun to fall, and many car companies are now planning to introduce new models. VW is introducing a number of new lower cost electric car models, Mercedes has accelerated plans for new electric vehicles to challenge Tesla (Shankleman, 2017) while Volvo has even announced it will phase out internal combustion powered cars by 2021 . City governments have also begun providing incentives for electric cars and Paris has announced it will ban internal combustion cars by 2030 (G. Smith, 2017). The IEA indicates that 10 governments,

\section{Evolution of Global Electric Car Stock}

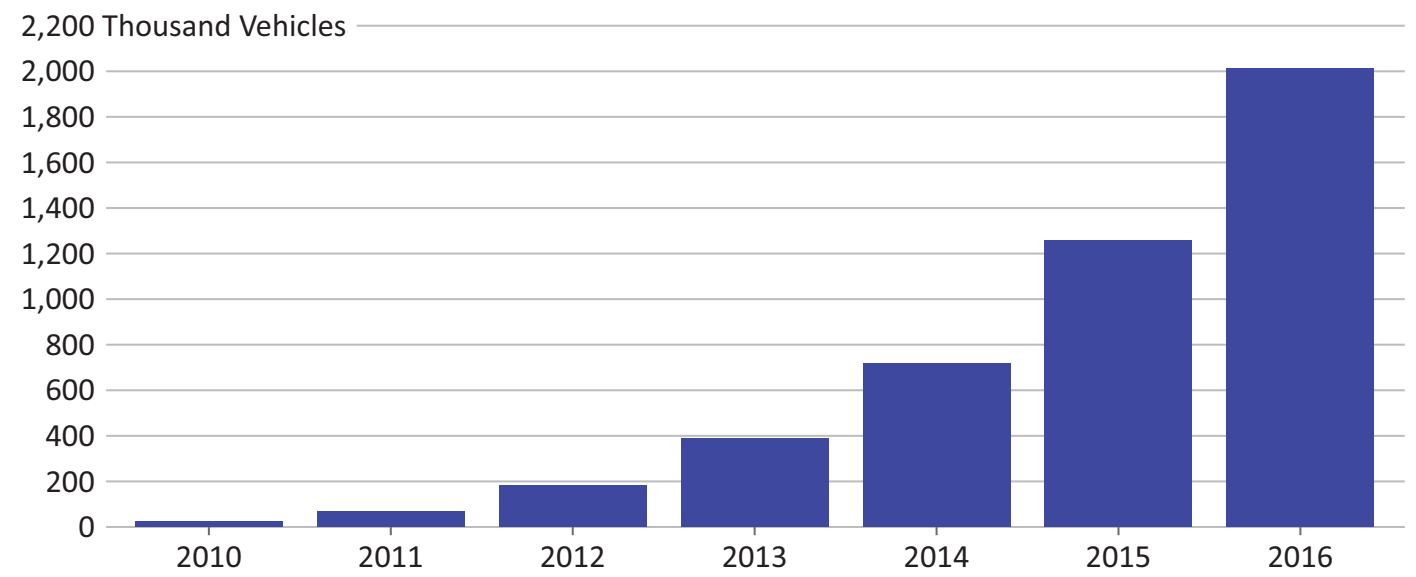

Figure 7. Growth of electric cars has begun to take off. Source: International Energy Agency (IEA, 2016). 
including China, France, Germany, the UK and US, will set a goal of $30 \%$ market share for battery powered cars, buses, trucks and vans by 2030 .

The Li-ion battery has now been mass produced, mostly in China, and has become the cheapest form of batteries for use in EV's (Nykvist \& Nilsson, 2015). Concerns about the source of Lithium have eased as most Lithium now comes from Western Australia where eight new mines have shown how widespread supplies of crustal Lithium can be refined for batteries. Recycling of Lithium and the other batteries does not seem to have the issues of Lead Acid batteries (Shi, Chen, \& Chen, 2018). Other batteries have different scientific advantages but for the next few decades of city building the Li-ion battery is likely to dominate and make solar households and businesses as well as solar transport a reality.

Whilst electric cars will significantly reduce local air pollution, their contribution to reducing greenhouse gas emissions depends on the source of their electrical energy. In countries such as France, with a high share of nuclear and renewable energy, replacement of petrol and diesel cars by electric cars will produce an immediate drop in transport-related greenhouse emissions. In countries like Australia, where $80 \%$ of electricity is currently coal-fired, there will be lower greenhouse benefits though even here it would be less. However, the shift to renewable energy has accelerated with dramatic growth rates in roof top solar (Green \& Newman, 2017; Newman, 2017a) and so the electric car revolution will eventually produce major reductions in greenhouse gas emissions.

\subsection{Autonomous Vehicles}

Another major technological change in transport is also underway-the development of autonomous or "driverless' vehicles. Companies such as Google are already driving such vehicles on regular streets around America to test their safety features. Singapore has trialled autonomous taxis and various trials of autonomous buses are underway including in Perth and Sydney. In the case of Sydney, an autonomous shuttle bus trial is underway at Olympic Park, being conducted jointly by the NSW Government, the National Roads and Motoring Association, the Sydney Olympic Park Authority and a number of private companies (Transport for NSW, 2018). Initially the shuttle bus will operate on dedicated routes, and later it will begin operating on public streets.

Autonomous (driverless) technology is also being applied to larger scale mass transit systems (see Figure 8). There are already a large number of driverless metro trains installed around the world, with a recent report benchmarking 25 systems (Wavestone, 2017). The International Railway Journal (IRJ) reports UITP estimates that the number of kilometres of driverless metros will ex-

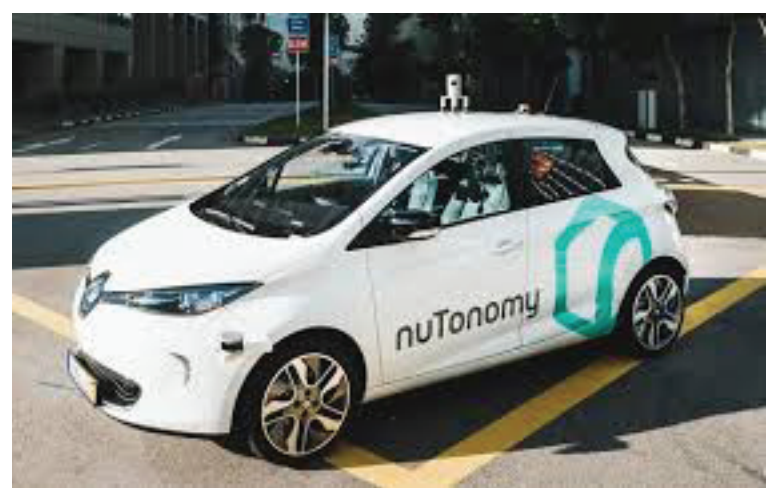

Autonomous taxi, Singapore.

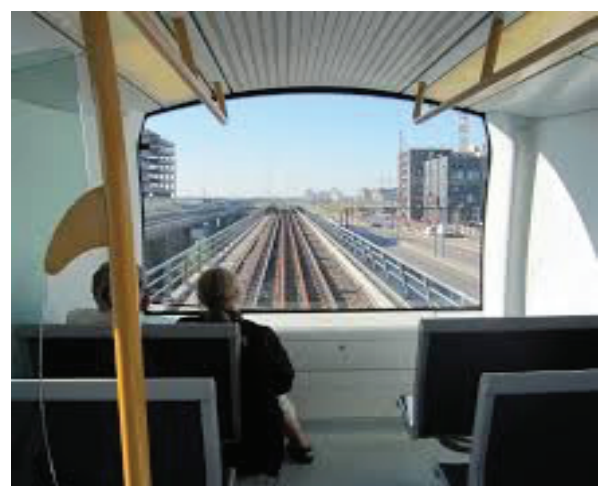

Driverless metros are becoming common more and more.

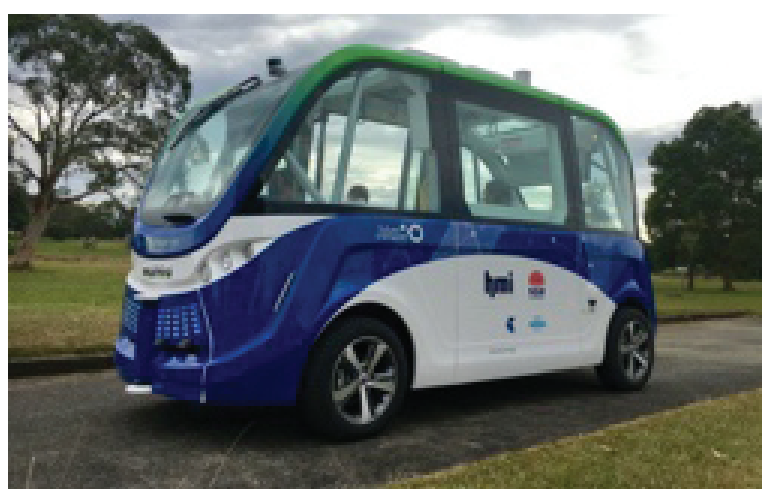

Autonomous shuttle bus, Sydney Olympic Park.

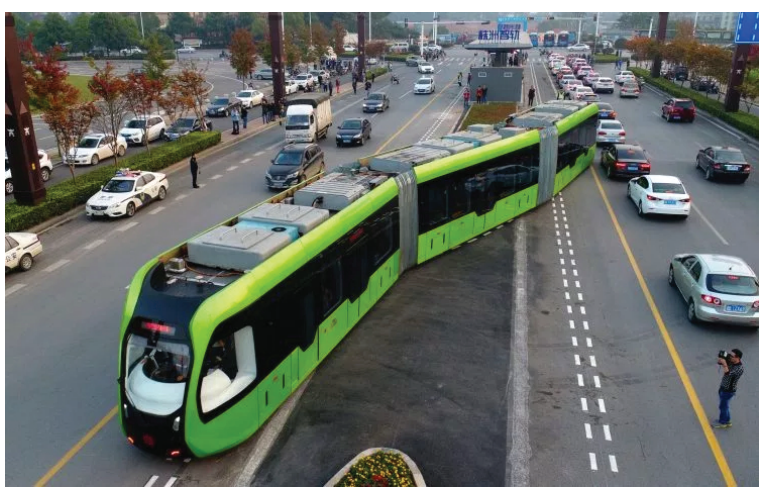

"Trackless" Tram being tested in China. The guidance system will allow future driverless operation.

Figure 8. Autonomous vehicles are on the way. Sources: Wavestone (2017), Transport for NSW (2018), Birginshaw (2017) and A. Smith (2017). 
pand from under 790 in 2016 to 2,200 by 2025 (Birginshaw, 2017). In addition, China has announced a new rubber-tired guided electric tram system which is being used in either driverless or driver mode and has the charcteristics of a light rail in terms of capacity, speed and potential ability to attract urban development (A. Smith, 2017).

Studies in the UK have estimated that the eventual replacement of conventional cars by driverless ones will result in a significant improvement in road safety, although the timeline for full autonomy in complex urban environments is likely to take some decades. However, if we simply replace privately owned vehicles with privately owned driverless vehicles, this will do little to reduce road congestion or parking requirements, or to make our cities more liveable.

However, if "communally" owned, a driverless vehicle could replace eight or more private vehicles, particularly if operated in a "continuous multihire" mode and if used to provide feeder services to rail and other mass transit systems or nearby activity centres. A single such vehicle could, for example collect two to five people, drive them to a rail station for the morning commute, then return empty to collect three or four more loads of commuters in the morning peak period. At the destination end autonomous vehicles could deliver commuters to offices or other facilities which were beyond the walking catchment of the station (destinations such as offices and shops are usually more concentrated than origins such as houses, with a higher proportion of people able to walk to them).

Thus, for example, one light rail vehicle plus a fleet of perhaps 15 autonomous vehicle shuttles (10 at the origin end and 5 at the destination end) could effectively replace 100 long-distance private car commuting trips (with a similar number in the reverse direction in the evening, plus additional avoided trips during the rest of the day). Figure 9 shows how this changes urban form.
This "last mile" service could substantially reduce the need for long distance trips by private cars, often with low car-occupancy (an average 1.2 passengers per vehicle is typical in most cities) which is the most energy and space intensive form of transport. This in turn could substantially reduce both road congestion (improving the efficiency of commercial vehicles) and the need for more road capacity, especially motorways.

In this context, the space saving attributes of mass transit over car-based systems is crucial. Arterial roads and motorways carry only around $1,000-2,000$ vehicles per lane per hour (1,500-3,000 passengers), whereas light rail, suburban rail and metros typically carry 3,00030,000 passengers per lane/track per hour, and are thus up to 10 times more space efficient (Newman \& Kenworthy, 2015).

Shifting a significant share of current automobilebased travel partially to mass transit will require additional capacity on urban rail and bus systems. However the scale of increase may not be as large as expected, given that there is significant spare capacity on such systems during off-peak periods, to smaller sub-centres and in counter-peak directions. In addition the mass transit mode shares to the city centres in peak periods is already very high in many cities. For example Sydney, which is a car-dependent city, nevertheless has an $80 \%$ public transport mode share for trips to the central business district in the morning peak.

Parking is another often hidden cost of our current car-based systems. In Sydney, it has been estimated that car parking occupies at least $100 \mathrm{sq}$. km. of land, worth in the order of $\$ 100$ billion if put to other uses (land values in Sydney have recently reached $\$ 1,000 / \mathrm{m}^{2}$ ).

In addition, the use of autonomous shuttles to feed rail or other mass transit can widen the catchment areas of the transit system, making them more economic in lower density suburban areas, or in cities where activities are highly dispersed.

\section{Current Commuting}

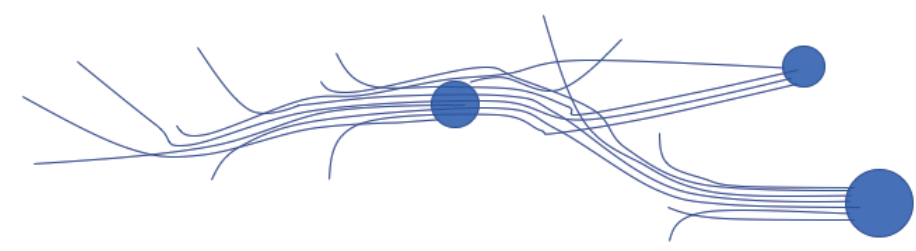

Future Commuting

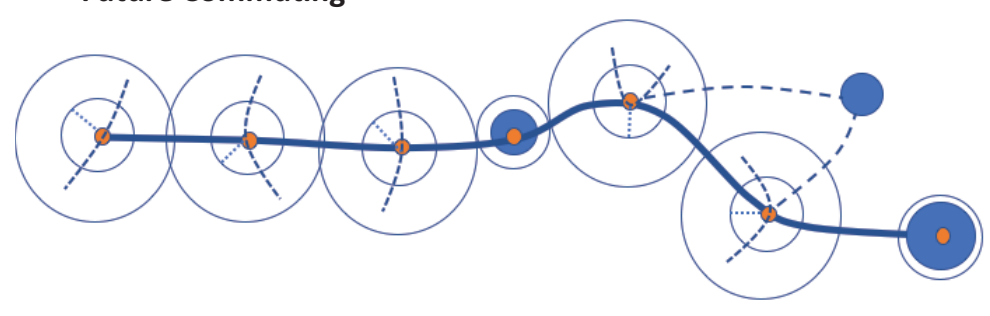

Destination

(e.g. office, retail)

Car Trip

Transit Line and Station

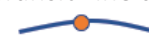

Autonomous Feeder -..-.......

Autonomous Distributor

Walking Trip

Station Walking Catchment

Figure 9. "Current" versus "future" commuting. Source: authors' own graphic. 
The future transport technologies are likely to be combinations of electric fast rail down high speed corridors plus electric light rail (or trackless trams) in lower speed corridors like inner areas, all building up substantial dense centres around stations as shown in Figure 9; into these centres the AV-EV technologies can feed in their last mile and first mile passengers as well as cycling and walking. In each of these centres electric charging from solar energy can provide zero carbon fuel for all the electric vehicles through rapid recharging points; the whole local solar and local transport system can be managed by a Citizen Utility using blockchain technology (Green \& Newman, 2017). Such an urban vision is unfolding rapidly before our eyes.

\subsection{Population Growth, the Information Economy and Urban Structure}

Cities have existed for at least 8,000 years, but it is only very recently that more than half of the world's population have lived in them. The process of urbanisation began in earnest in the UK with the industrial revolution, moved to other European countries and North America and is continuing now in China, India, Indonesia and other developing economies, especially in Africa.

This process has fuelled and been fuelled by a rapid increase in energy consumption, accompanied by rising living standards, the development of high-rise buildings and the growth in automobile ownership. In many places cars have taken over streets previously dominated by pedestrians and cyclists. Cities have also expanded in size, increasing trip lengths beyond what is feasible for non-motorised transport.

However, the patterns of urbanisation and city structure have not been uniform between cities and countries. In Europe, cities have continued to be built at relatively high densities, although there has been some "suburban sprawl" on the city outskirts. However, many European cities have retained the strong public transport orientation which accompanied their early development phase

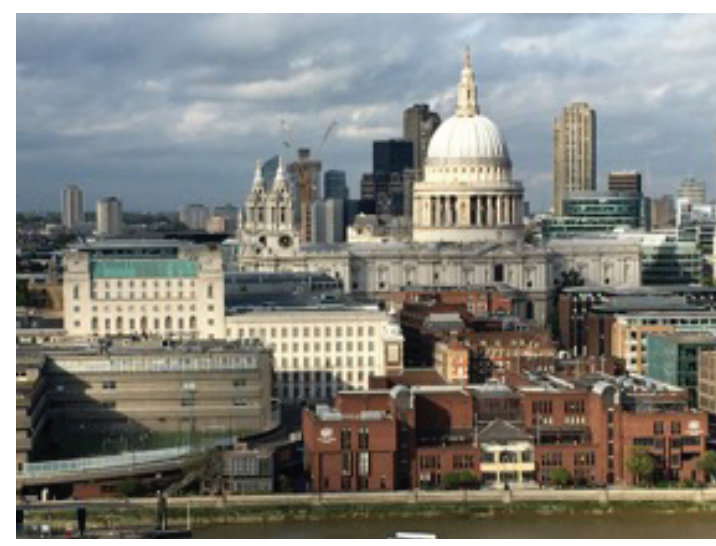

London is adding high rise buildings to an already dense urban core. at the end of the 19th and beginning of the 20th centuries (Figure 10).

In contrast, most "new world" cities have experienced most of their urban growth in the age of the automobile-from 1920 to 2000 . Accordingly, they have been built at very low densities and with extensive motorways and parking but limited public transport networks (Figure 10). However some of these cities (for example the State capital cities in Australia and many cities in the south or west of the United States) continue to experience rapid population growth. This provides opportunities for densifying these cities, especially along rail corridors or around emerging sub-centres as is already occurring in cities such as Sydney as discussed earlier.

At a global level, the focus of urbanisation is now on countries in Asia, the Middle East and Africa. This third phase of urbanisation is producing high-density cities which nevertheless cover large areas and house $10 \mathrm{mil}-$ lion or more inhabitants. In many of these cities, there has been a rapid rise in car ownership and use alongside significant investment in metros and other public transport (Figure 11). In China for example, Beijing and Shanghai have built metro systems in just thirty years which now dwarf the traditional metros of European cities and associated with this they are now showing peak car as both urban rail and electric bikes are growing rapidly (Gao \& Newman, 2018).

The urban structure of different cities also varies. European cities typically have $30 \%$ or more of their total employment in the central area, supported by strong radial public transport systems. US cities typically have only around $10 \%$ of their total employment in the "city centre", but with a significant share of jobs located in sub centers and "edge cities", often located at the intersection of radial and circumferential motorway systems (Karanfilovski \& Stone, 2015). The mega cities of Asia tend to have multiple centres of economic activity like Singapore which has 22 sub centers (Newman \& Matan, 2013).

However in almost every city the urban planners are looking to reduce automobile dependence through a

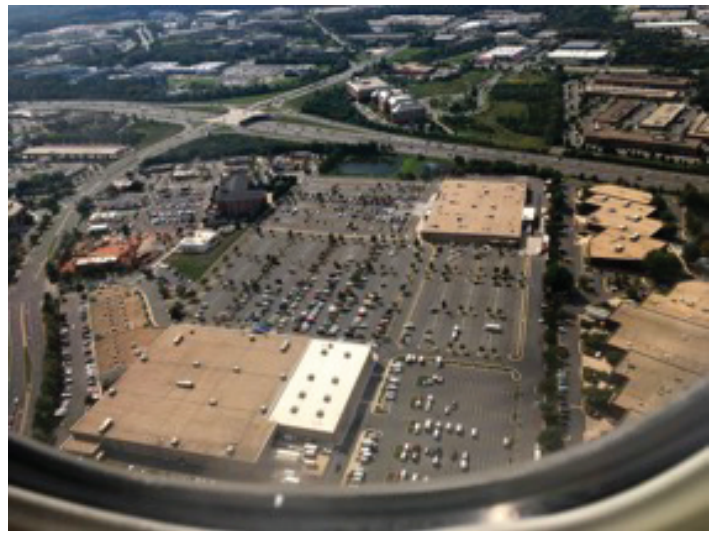

Outskirts of Washington DC illustrates car-oriented urban development.

Figure 10. Urban development contrasts. 


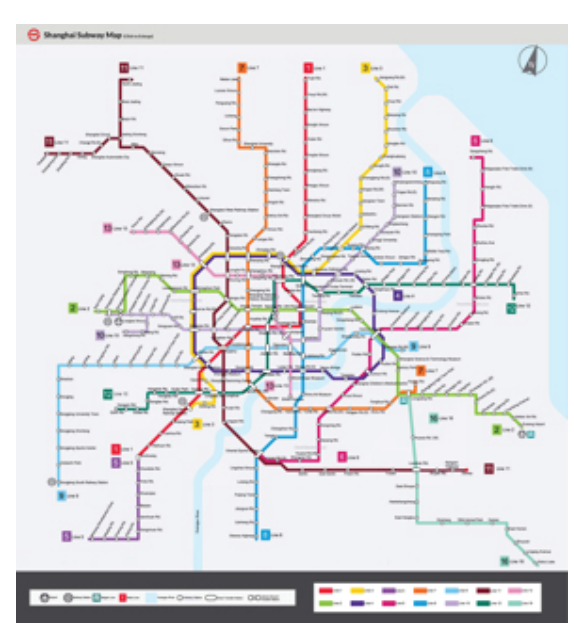

Shanghai's metro network.

$\begin{array}{llll}\text { CITY } & \begin{array}{l}\text { PATRONAGE } \\ \text { (Billion) }\end{array} & \begin{array}{l}\text { LENGTH } \\ (\mathrm{Km})\end{array} & \text { STATIONS } \\ \text { Beijing } & 3.4 & 527 & 319 \\ \text { Shanghai } & 2.8 & 548 & 337 \\ \text { Seoul } & 2.6 & 332 & 311 \\ \text { Tokyo } & 3.3 & & 179 \\ \text { Moscow } & 2.5 & 328 & 196 \\ \text { Mexico City } & 1.6 & 228 & 195 \\ \text { New York } & & 373 & 468 \\ \text { Paris } & 1.5 & & 303 \\ \text { London } & 1.3 & 402 & 270 \\ \text { Madrid } & & 294 & 301 \\ \text { Guangzhou } & 2.3 & 240 & \\ \text { Nanjing } & & 224 & \\ \text { Hong Kong } & 1.7 & & \end{array}$

Hong Kong

1.7

Source: http://www.citymetric.com/transport/what-largest-metro-system-world-1361

World's busiest metro systems.

Figure 11. The emergence of the metro in the new mega cities of Asia. Source: Travel China (n.d.).

combination of improved transit and a polynuclear urban form focussing on rail stations (Newman \& Kenworthy, 2015). This is being done not just for transport and energy reasons but also for the multiple benefits in social, economic and environmental factors that this can bring. Thus the 1.5 으 agenda with its zero carbon goal as well as the need to fulfil the Sustainable Development Goals, is likely to see more focus on this kind of urban planning.

\section{The City of the Future}

There have been many futuristic scenarios for how cities will change and what transport systems we will use to get around them. Visions from the 19th century and early 20th century often featured electric trains or even gigantic steam engines (Figure 12) while later 20th century visions frequently include personal transport from cars to personal flying machines.

Many of these "visions" came from architects and others with only superficial knowledge of the economics of different transport technologies or modes. Many also envisaged high-rise cities patterned after New York. Indeed some extremely tall buildings are emerging, and new developments such as flexible lifts which can move sideways as well as vertically, may change building economics.
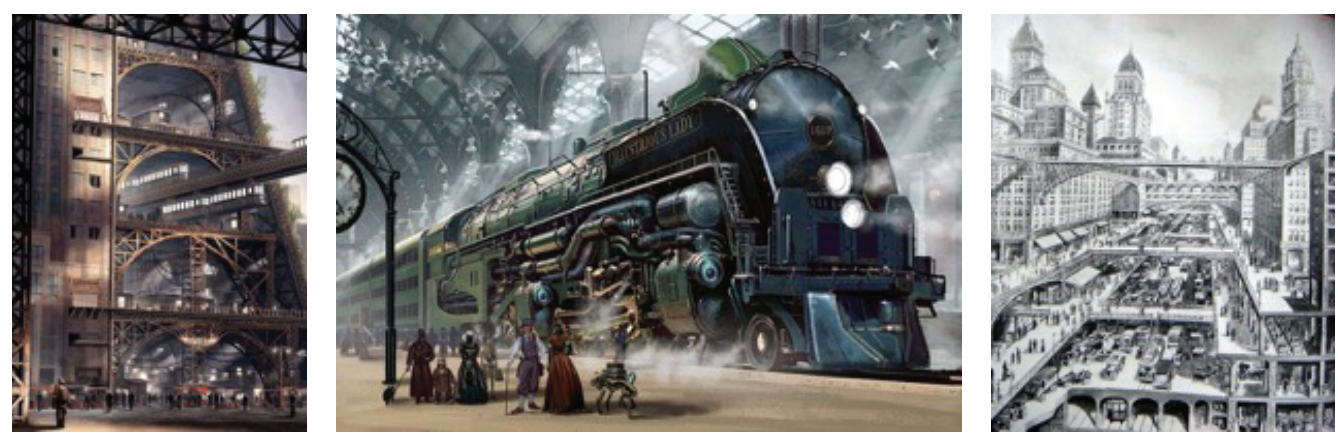

19th century visions of the future city focused on multi-level cities and mass transit.
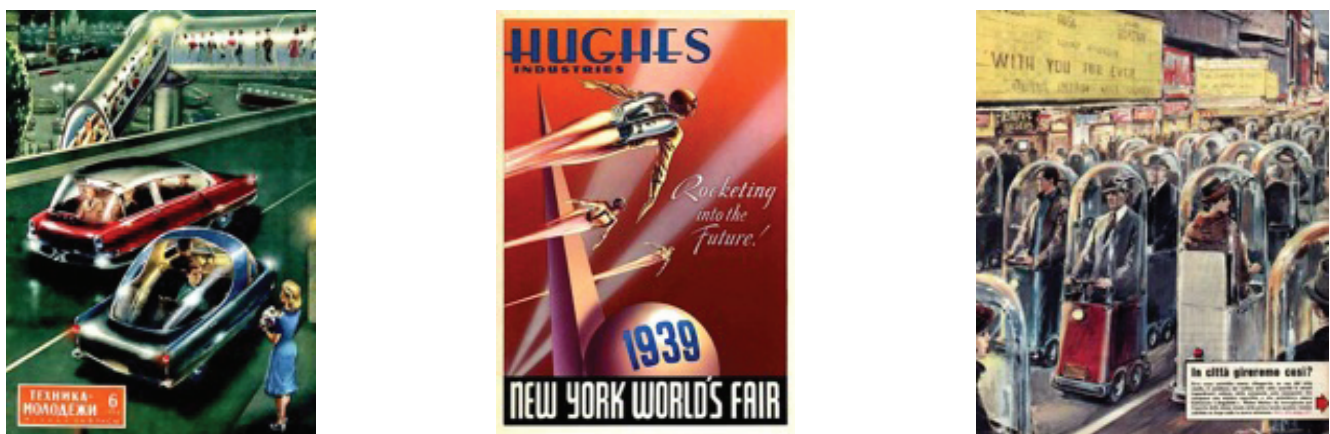

20th century visions of the future focused on individualised transport systems.

Figure 12. Past visions of the City of the Future. 
At the same time, as discussed earlier, cities are now becoming denser again after the period of urban sprawl in the late 20th century. This will reduce per capita travel requirements but requires efficient high-capacity modes if high levels of congestion are to be avoided. This is a major motivation behind the second rail age.

It now seems likely that many cities will continue to increase in both population and density, but that it is unlikely that "vertical" cities, "underwater" cities or other more fanciful constructs will replace the basic pattern of individual buildings connected by road and public transport networks. Urban fabrics last for many generations based around walking, transit and the automobile and they are likely to be the main combinations for many generations into the future, perhaps with even more walking urban fabric and transit urban fabric (Newman et al., 2016). Even the idea of the "non place urban realm" where all work and social interaction was done through electronic communications, has not emerged; instead the knowledge economy has facilitated "face-to-face" interactions in urban centers and has fed the regeneration of older urban fabric designed around walkability (Matan \& Newman, 2017; Newman \& Kenworthy, 2015). What can change however is the more precise urban structures within cities and the shares of transport undertaken by different modes and the role that new technologies are likely to play in shaping this City of the Future as set out in this article. But the trends are still likely to grow out of the functional arrangements of how cities facilitate commerce and provide social opportunities, thus ensuring that in the City of the Future the ancient walking city, the 19th and early 20th century transit city, and the modern automobile city are recognised, respected and regenerated by the new urban development processes (Newman et al., 2016). The new technologies discussed below are indeed enabling such recognition and rejuvenation.

Economic forces are likely to mean continued clustering of activities both to reduce transport costs and because of basic human social needs. Despite well over 100 years of the telephone, and thirty years of the internet, people still value face-to-face communication. Communications technology has not led to a displacement of travel-it appears to be a complement rather than a substitute. However the new use of ICT is to create smart control systems that offer a city much more than entertainment but a more efficient and sustainable transport system.

The long car-based commutes to work common in many cities now need not always be the norm. These derive from the unfortunate combination of the spread-out city and the growing specialisation of the labour force. While the rise of the car favoured the former, the rise of the information economy ironically favours greater clustering of activities into centres-as evidenced by the emergence of the suburban "office park" and satellite city centres in many cities, as well as the revitalisation of the traditional central business districts and inner urban areas (Thomson, Newton, \& Newman, 2016).
This points to a City of the Future based on the emerging transport technologies highlighted in the previous section and on the emerging information economy with increasingly specialised business and human service sector jobs. This city is likely to have:

- An increased concentration of jobs, residents and other activities in both the traditional CBD, along old transit corridors, and in satellite cities and sub-centres clustered around intensive rail systems. These centres will be accessible from the local areas by walking, cycling, and small scale electric vehicles, and from the wider metropolitan region by the combination of local access modes and mass transit;

- All modes will be electric and their power will be renewable. Local management of electric power, integrated with local shared mobility systems, will emerge;

- Increasing densities for housing in all parts of the city, especially around stations, but with more open space and less urban "sprawl";

- A concomitant decline in the share of "dispersed" activities, which will fail to achieve the economies of scale and scope possible with clustering;

- New and expanded mass transit systems providing better access to the CBD and sub centres with higher speed and capacity based around autonomous technology; subsequent reductions in road capacity and road infrastructure spending followed by some dismantling of freeways;

- The replacement of many private automobile trips by the combination of local access modes, mass transit and shared-use autonomous vehicles;

- A marked reduction in overall traffic volumes on the road network. This will allow some road-space to be re-allocated from cars to either trucks and commercial vehicles (which may also be driverless in some cases) or to bicycles, scooters other small personal mobility devices and to more intensive urban activity;

- A significant reduction in parking. This space can be re-allocated to higher uses, including additional commercial, office, retail, housing, public open space or other uses such as 'parklets' that facilitate local businesses;

- The changes in transport and land use will improve accessibility, reduce the individual, social and environmental costs of travel and improve housing affordability.

\section{Case Study: Transformation of Sydney}

What could the City of the Future look like? To explore that question, we examine an Australian city, Sydney, which is a medium sized city (on the world scale) in terms of population, but which is still very car dominated.

Sydney is Australia's largest city, with a population in 2016 of 4.6 million. It is also one of the world's fastest 
growing cities, with population increasing by $25 \%$ over the last twenty years.

Founded in 1788, Sydney grew rapidly in the first railway age, developing around an expanding tram and suburban rail network. Indeed, Sydney's trams moved more people in 1944 than all current light rail systems in the US put together. While the trams were replaced from the 1950's with buses, a large suburban rail system survived, which has over 200 stations, 2,000 double-deck rail carriages, and carried 360 million passengers in 2016.

Sydney was slower than most US cities to develop urban motorways, in part because of community opposition. However, between about 1970 and 2010 Sydney developed an extensive toll-way network, much of it in tunnels. During the same period, public transport investment was minimal. As a result, car travel came to dominate travel patterns by the turn of the century.

Forecasts by the Bureau of Transport Statistics a few years ago suggested that private car travel would continue to dominate urban travel patterns, notwithstanding the trend back to mass transit since 2005 noted earlier.

However, after forty years of neglect, Sydney is now also investing $A \$ 20$ billion in its rail and public transport systems. Major projects are outlined below:

- A new $24 \mathrm{~km}$ automated metro line is under construction to the North-Western suburbs and will open in 2019, a second extension through the CBD to the south-western suburbs is also under construction and is due to open by 2024 , and a third metro line has been announced and is currently being planned for completion by the late 2020s;
- The existing large-scale "suburban rail" system, which includes a small underground section in the city centre, is also being upgraded with additional rollingstock and improved services;

- The Inner West light rail line was extended a few years ago, with patronage quadrupling to $10 \mathrm{mil}-$ lion passengers. A new CBD and South-East light rail line is now under construction, also to be opened in 2019-it will feature the longest trams in the world and is likely to carry at least 50 million passengers annually from its opening. A third light rail system has been announced for Parramatta, due to open by 2024-2025;

- The bus system has been modernised and frequencies increased with metro buses, and a major new busway is planned for the Northern Beaches;

- A second ferry terminal in the CBD has been recently opened with additional ferries being added to the fleet.

In addition, Sydney finally implemented its "OPAL" smartcard ticketing system in 2012, making travel by public transport much more convenient, especially for multimode trips. As a result, public transport patronage has increased by over $30 \%$ in the last six years, and the rate of increase has recently accelerated.

Indeed, as noted in a recent report by the AuditorGeneral, train patronage increased by nearly $11 \%$ in $2015 / 6$, bus patronage by $12 \%$ and light rail patronage by $60 \%$, compared with a year earlier (see Table 1 ).

Another factor behind the rapid rise in public transport usage has been higher density development around existing public transport nodes. Figure 13 below shows

Table 1. Public transport patronage in Sydney (millions) 2009-2010 to 2015-2016. Source: Transport for NSW (2017).

\begin{tabular}{|c|c|c|c|c|c|c|c|}
\hline Year & $2009 / 10$ & $2010 / 11$ & $2012 / 13$ & $2013 / 14$ & $2014 / 15$ & $2014 / 15$ & $2015 / 16$ \\
\hline Rail & 289 & 294 & 302 & 306 & 312 & 326 & 361 \\
\hline Bus & 210 & 214 & 219 & 220 & 224 & 257 & 290 \\
\hline Light rail & 3 & 3 & 4 & 4 & 4 & 6 & 10 \\
\hline Ferry & 14 & 15 & 15 & 15 & 16 & 15 & 15 \\
\hline Total & 516 & 525 & 540 & 545 & 556 & 604 & 676 \\
\hline 2009/10 BAS & $100 \%$ & $102 \%$ & $105 \%$ & $106 \%$ & $108 \%$ & $117 \%$ & $131 \%$ \\
\hline
\end{tabular}

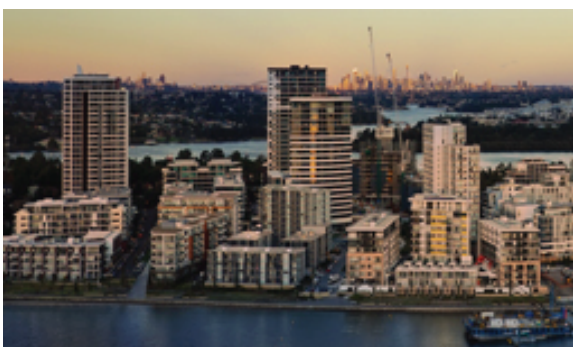

High rise development at Rhodes.

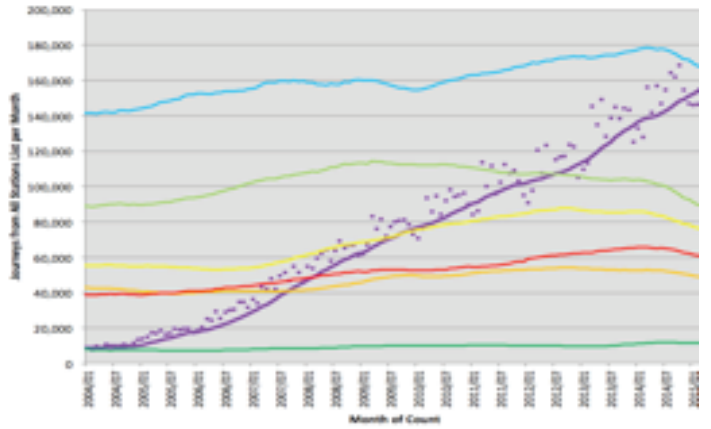

Boardings at Rhodes and neighbouring stations.

Figure 13. Impact of transit-orientated development on patronage. Source: Transport for NSW (2017). 
one example-high rise units around Rhodes station, about half way between the $\mathrm{CBD}$ and the growing second CBD of Parramatta. Figure 13 shows the rapid growth in patronage at Rhodes station, which has increased 16-fold in a decade to over 5,000 boardings per day.

With the upgrades to rail, light rail, bus and ferry either under construction, or announced and in detailed planning, the authors estimate that Sydney's public transport patronage could potentially double in the next fifteen years to almost 1.3 billion passengers by 2030 (see Figure 14).

While this would be impressive, it would still leave Sydney as a relatively car-dependent city in 2030 . However, with further investment in mass transit over the subsequent 25 years, and with the intelligent use of autonomous vehicle technology, Sydney could be a very different city by 2056. If these kinds of growth trends were the basis of urban growth it would be possible to essentially phase out oil from Sydney's passenger transport system.

The State Government has recently updated its transport plan for Sydney and extended it to a "vision" for 2056 (see Figure 15). This vision assumes Sydney will evolve into a region of 8 million population, with three connected sub-regions, the Eastern City centred on the traditional CBD, a Central Sydney based on Parramatta, and a Western City based on the opportunities around the Second Sydney Airport together with further devel-

\section{Potential Public Transport Trips (Million) by Mode in Sydney: $2005 / 6$ to $2030 / 31$}

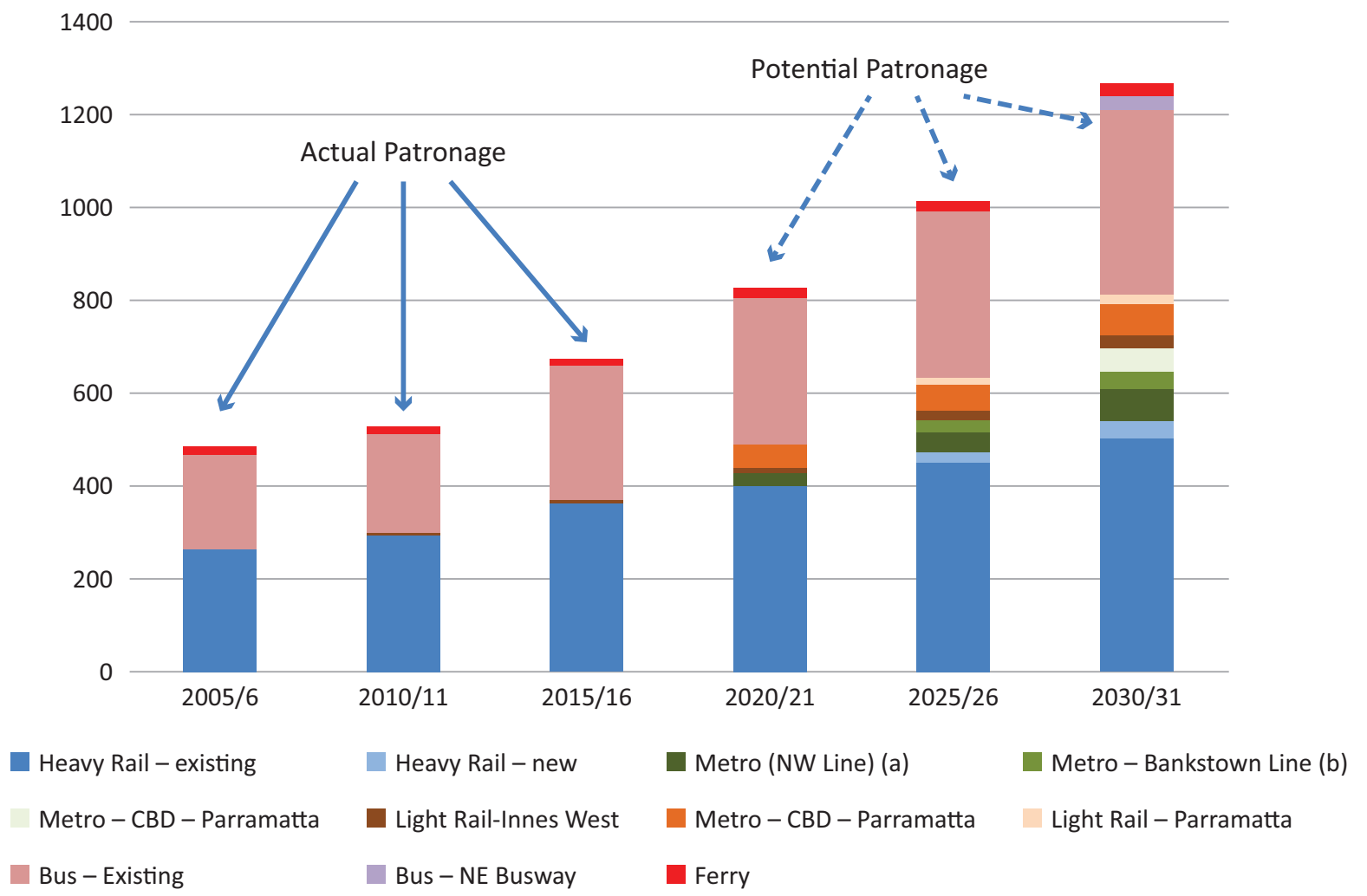

Figure 14. Actual and potential public transport patronage growth in Sydney: 2005-2006 to 2030-2031. Source: Transport for NSW (2017).
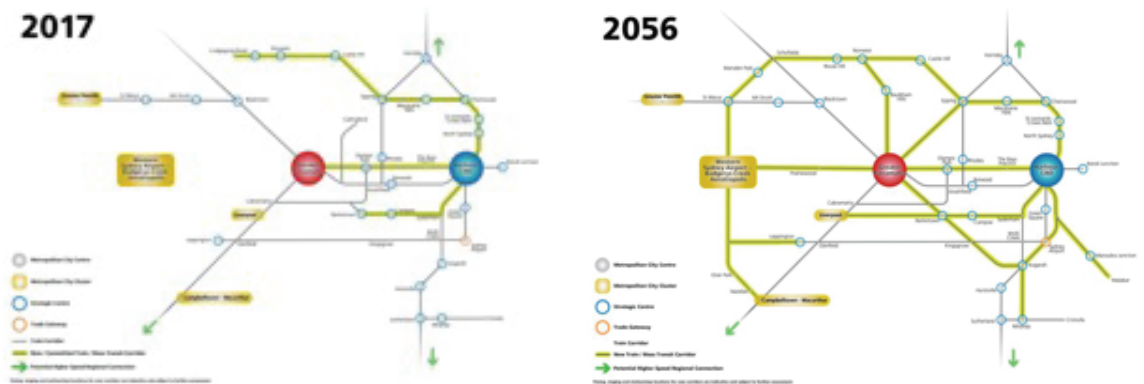

Sydney's mass transit system. Left: existing and committed links; right: vision for 2056.

Figure 15. Current and potential future mass transit system for Sydney. Source: Transport for NSW (2017). 
opment at sub-centres including Penrith, Blacktown and Campbelltown. Each city would have a range of heavy rail, metro and light rail links, and the three centres would be located along the Metro West project, currently in planning. In addition, the 2056 vision assumed development of autonomous vehicles, which in conjunction with mass transit, will replace many private car trips.

A somewhat modified proposal for 2056 by the authors below shows how freight as well as high speed rail, together with a more extensive light rail network, could further enhance this vision.

Figure 17 shows the amount and shares of travel in Sydney in 2056 by different modes which would be possible under such a scenario. This assumes that over the next forty years:
- Population grows by $60 \%$ (average componund growth rate of $1.2 \%$ pa) to 7.5 million;

- Average Trip length decreases by $10 \%$ (with better distribution of employment etc);

- Total Travel (Passenger-kms) on Mass transit quadruples by $2055 / 56$, with an average compound growth of $3.6 \%$ pa over the next 40 years;

- $20 \%$ of private car trips shift to shared-use autonomous vehicles and mass transit by then.

Under this scenario, total $\mathrm{CO} 2$ emissions from urban passenger transport could be almost eliminated, assuming by 2056 that $100 \%$ of all electricity in the Eastern Australian Grid is generated from solar, wind, hydro, geothermal or other forms of renewable energy, and that $90 \%$

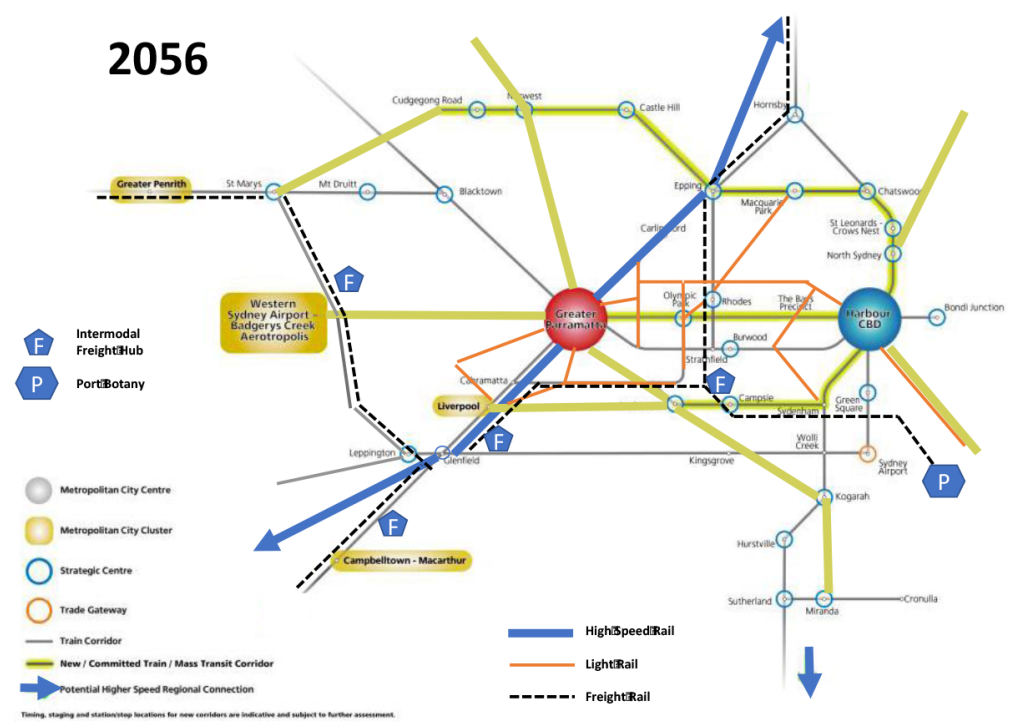

Figure 16. Modified potential future mass transit system for Sydney. Source: Transport for NSW (2017) and authors.

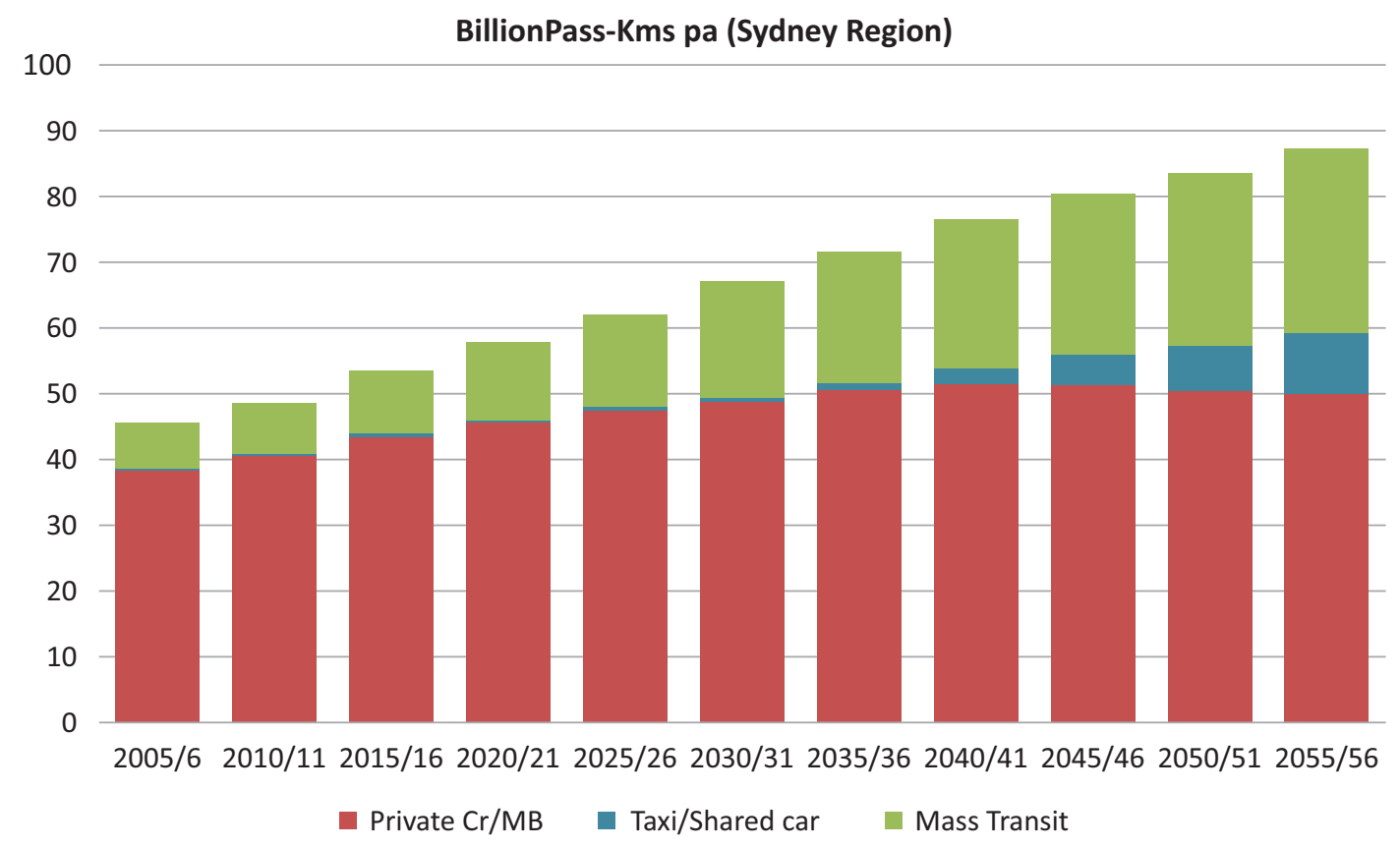

Figure 17. Potential future trends in travel in the Sydney region. Source: Transport for NSW (2017) and authors. 
of all cars, buses and taxis are electrically powered by then. In addition, total private car traffic would level off after about 2030, notwithstanding the continuing population growth, suggesting no need for additional urban freeways beyond those currently under construction.

\section{Making It Happen: How Government Can Act}

Cities are built by a combination of public and private investment. But while the private sector is essential, the public sector plays a crucial role in determining the shape and overall liveability of the city for its inhabitants.

The previous discussion has outlined how we can transform our cities. How can governments encourage this transformation? The following are suggested:

- Slow or stop investment in urban motorways (Gaynor et al., 2017);

- Accelerate investment in mass transit systems, especially electric rail-based systems, including through new partnerships with the private sector (Newman et al., 2017);

- Encourage integrated development around rail stations and other key transit nodes and discourage further development remote from rail corridors;

- Provide walkable town centres and safe cycle-ways for local travel, including access routes to town centres, schools and transit hubs;

- Encourage the development of companies or nonprofit community organisations which can be Citizen Utilities as well as own and operate fleets of shared local mobility services, autonomous electric cars and small electric buses to act as feeders to transit hubs from areas outside the walking catchments;

- Enable the rapid general introduction of electric vehicles, both cars, buses and e-bikes with recharging facilities based on solar energy;

- Gradually introduce road pricing and parking policies to encourage people to reduce their private car ownership and use and help pay for infrastructure;

- Accelerate the transition from coal and gas-fired electricity to renewable energy, especially rooftop solar in all new residential and commercial urban developments, especially new green transit oriented developments;

- Facilitate the involvement of new governance along corridors of sub centres based on alternative funding and financing of electric rail systems and associated transit oriented developments through new urban partnerships.

The integration of all these policies into urban planning and development is possible if governments at all levels set up partnerships with private financing (especially superannuation companies looking for long term investments), developers (who understand markets and inno- vation in urban development) and communities (who know what they want for their precincts and neighbourhoods for the long term). This kind of partnership which integrates rather than does urban development based on separate silos of professional practice and sectoral advice, has been rapidly growing across the world (Clark \& Clark, 2014; Newman, 2016). This is particularly important for the kind of urban developments outlined here for the City of the Future and new ways of bringing the partnerships together are being created that use private funding to help with the big capital costs of transit building (Newman, Davies-Slate, \& Jones, 2017)

In Australia, the new partnerships are being called City Deals following the approach taken by the UK but with more specific requirements to enable:

- Partnerships with three levels of government that set out the plan for the City Deal;

- Community support for the projects;

- Private involvement in the financing through integration of land development and transit, backed up with some funding from local and state government and a risk guarantee from the national government.

The outcomes of the City Deals need to show transformational urban development with clear provision of affordable housing and sustainability objectives including the commitments to decarbonizing development. Such City Deals put urban planning firmly on the national agenda and demonstrate how the City of the Future can be created.

\section{Conclusions}

For the last 60 years, motorways were seen in many cities as essential tools to "unblock" the arteries of the city. But experience has shown that without matching investment in mass transit, and policies to manage car use, this only led to unconstrained urban sprawl and a range of environmental, health and other side effects.

One of these is the growing contribution of transport, especially car use, to global warming. Even without this threat, the motorway model of urban development has been seen to fail. The added pressure to deal with climate change provides an opportunity to re-envision how our cities and their transport systems can be built to improve environmental, social and economic outcomes.

The key is to use new technologies intelligently, building organically on the urban fabric of the past, and to see the privately owned and operated car as a luxury we no longer need or can afford. Cars certainly have their place and their two-dimensional flexibility will always make them an attractive and in some cases efficient option for cross-suburban travel. But they are not ideal for travel to centres or places of high concentrations of activities. For that, mass transit has shown it is the preferred solution supported by high quality and walking and cycling 
infrastructure to support intensive urbanism in centres. At the same time, the transition from privately owned petrol or diesel cars to community owned autonomous electric vehicles, as well as to bicycles and small electric vehicles, in combination with much greater use of mass transit, provides a unique opportunity for citizens to reclaim their cities from the dominance of the car. The City of the Future is likely to have an electricity system that is totally renewably powered and a passenger transport system that is completely electric. Nothing short of this is required given the climate crisis we face. It is also a city with significant attractions for social and economic opportunities that cities have provided for centuries and which they will need to provide for the future.

\section{Acknowledgments}

The authors would like to acknowledge their university support and professional practice support in many cities over several decades of research on the best future for cities, transport and energy.

\section{Conflict of Interests}

The authors declare no conflict of interests.

\section{References}

Anas, A., Arnott, R., \& Small, K. A. (1998). Uban spatial structure. Journal of Economic Literature, 36(3), 1426-1464.

APTA. (2016). Fact book, appendix A. American Public Transit Association. Retrieved from http://www. apta.com/resources/statistics/Pages/transitstats.aspx

Batty, M., \& Longley, P. (1994). Fractal cities: A geometry of form and function. London: Academic Press.

Birginshaw, D. (2017). Automated metros set to reach $2200 \mathrm{~km}$ by 2025 . International Railway Journal. Retrieved from http://www.railjournal.com/index. $\mathrm{php} / \mathrm{metros} /$ uitp-forecasts-2200km-of-automatedmetros-by-2025.html

BITRE. (2014). Urban public transport: Updated trands. Information sheet 59. Canberra: Department of Infrastructure and Regional Development. Retrieved from https://bitre.gov.au/publications/2014/files/is _059.pdf

Bratzel, S. (1999). Conditions of success in sustainable urban transport policy: Policy change in "relatively successful" European cities. Transport Reviews, 19(2), 177-190.

C40. (2017). Focused acceleration: A strategic approach to climate action in cities to 2030. McKinsey Centre for Business and Environment. Retrieved from C40production-images s3.amazonaws.com

Carlin, K., Rader, B., \& Rucks, G. (2015). Interoperable transit data: Enabling a shift to mobility as a service. Basalt, CO: Rocky Mountain Institute. Retrieved from https://rmi.org/wp-content/uploads/2017/03/
Mobility-InteroperableTransitData-Report.pdf

Clark, G., \& Clark, G. (2014). Nations and the wealth of cities: A new phase in public policy. London: Centre for London.

Frey, H. (1999). Designing the city: Towards a more sustainable urban form. London; New York, NY: Taylor \& Francis Group/Spon Press.

Gao, Y., \& Newman, P. (2018). Beijing's peak car transition: Hope for emerging cities in the $1.5^{\circ} \mathrm{C}$ agenda. Urban Planning, 3(2), XX-XX.

Gaynor, A., Newman, P., \& Jennings, P. (2017). Never again reflections on environmental responsibility after Roe 8. Perth: UWA Scholar Press.

Goodwin, P., \& van Dender, K. (2013). Peak car: Themes and issues. Transport Policy, 33(3), 243-254. doi:10.1080/01441647.2013.804133

Green, J., \& Newman, P. (2017). Citizen utilities: The emerging power paradigm. Energy Policy, 105, 283293. doi:10.1016/j.enpol.2017.02.004

IEA. (2016). Global EV outlook 2016: Beyond one million electric cars. Paris: International Energy Agency. Retrieved from https://www.iea.org/publications/free publications/publication/Global_EV_Outlook_2016. pdf

IEA. (2017a). Key world energy statistics. Paris: International Energy Agency. Retrieved from https://www. iea.org/publications/freepublications/publication/ KeyWorld2017.pdf

IEA. (2017b). Energy efficency indicators: 2017 database. Paris: International Energy Agency. Retrieved from http://www.iea.org/statistics/topics/energyefficiency/

IEA., \& UIC. (2016). Railway handbook 2016. Energy consumption and $\mathrm{CO} 2$ emissions: Focus on sustainability targets. Paris: International Energy Agency/International Union of Railways. Retrieved from http://uic.org/IMG/pdf/iea-uic_railway_hand book_2016.pdf

IPCC. (2014a). Fifth assessment report (AR5). Geneva: Intergovernmental Panel on Climate Change. Retrieved from https://www.ipcc.ch/report/ar5/mindex.shtml

IPCC. (2014b). Climate change 2014: Mitigation of climate change. Contribution of working group III to the fifth assessment report of the intergovernmental panel on climate change. Cambridge; New York, NY: Cambridge University Press.

Karanfilovski, G., \& Stone, J. (2015). The spatial distribution of the travel to work by sustainable transport modes in Australian cities from 2001 to 2011. Australasian transport research forum 2015 proceedings, 30 September-2 October 2015. Retrieved from http://www.atrf.info/papers/index.aspx

Kramers, A., Wangel, J., Johansson, S., Höjer, M., Finnveden, G., \& Brandt, N. (2013). Towards a comprehensive system of methodological considerations for cities' climate targets. Energy Policy, 62, 1267-1287. http://doi.org/10.1016/j.enpol.2013.06.093

Lynch, K. (1981). A theory of good city form. Cambridge, MA: MIT Press. 
Matan, A, \& Newman, P. (2017). People cities: The life and legacy of Jan Gehl. Washington, DC: Island Press.

Mittal, S., Dai, H., \& Shukla, P. R. (2016). Low carbon urban transport scenarios for China and India: A comparitive assessment. Transport Research Part DTransport Environment, 44, 266-276. doi:10.1016/ j.trd.2015.04.002

Moriarty, P., \& Honnery, D. (2013). Greening passenger transport: A review. Journal of Cleaner Production, 54(1), 14-22. doi: 10.1016/jclepro 2013.04.008

Newman, P. (2016). Sustainable urbanization: Four stages of infrastructure planning and progress. Journal of Sustainable Urbanization, Planning and Progress, 1(1), 3-10. doi:10.18063/JSUPP. 2016.01.005

Newman, P. (2017a). The rise and rise of the renewable city. Renewable Energy and Environmental Sustainability, 4(2), 1-5. doi:10.1051/rees/2017008

Newman, P. (2017b). Decoupling economic growth from fossil fuels. Modern Economy, 8(6), 791-805. doi:10.4236/me.2017.86055

Newman, P., Beatley, T., \& Boyer, H. (2017). Resilient cities: Overcoming fossil fuel dependence (2nd ed.). Washington, DC: Island Press.

Newman, P., Davies-Slate, S., \& Jones, E. (2017). The entrepreneur rail model: Funding urban rail through majority private investment in urban regeneration. Research in Transportation Economics, 2017, 1-10. doi:10.1016/j.retrec.2017.04.005

Newman, P., Glazebrook, G., \& Kenworthy, J. (2013). Peak car and the rise of global rail: Why this is happening and what it means for large and small cities. Journal of Transportation Technologies, 3(4), 272287. doi:10.4236/jtts.2013.34029

Newman, P., \& Kenworthy, J. (1989). Cities and automobile dependence. Aldershot: Gower,

Newman, P., \& Kenworthy, J. (1999). Sustainability and cities: Overcoming fossil fuel dependence. Washington DC: Island Press.

Newman, P., \& Kenworthy, J. (2011). Peak car use: Understanding the demise of automobile dependence. World Transport Policy and Practice, 17(2), 32-42.

Newman, P., \& Kenworthy, J. (2015). The end of automobile dependence: Moving beyond car based planning. Washington, DC.: Island Press.

Newman, P., Kosonen, L., \& Kenworthy, J. (2016). Theory of urban fabrics: Planning for walking, transit and automobile cities for reduced automobile dependence. Town Planning Reviews, 87(4), 429-458. doi:10.3828/tpr.2016.28

Newman, P., \& Matan, A. (2013). Greenurbanism in Asia. Toh Tuck: World Scientific Publications.

Nykvist, B., \& Nilsson, M. (2015). Rapidly falling costs of battery costs for electric vehicles. Nature Climate Change, 5, 329-332. doi:10.1038/nclimate2564

Rapier, G. (2017). Bank of America: We've reached peak car. Business Insider. Retrieved from https:// www.businessinsider.com.au/bank-of-america-weve -reached-peak-car-2017-6? $r=U S \& I R=T$

Shankleman, J. (2017). Electric car sales are surging (IEA Reports). Retrieved from https://www. bloomberg.com/news/articles/2017-06-07/electriccar-market-goes-zero-to-2-million-in-five-years

Shi, Y., Chen, G., \& Chen, Z. (2018). Effective regeneration of LiCoO2 from spent lithium-ion batteries: A direct approach towards high-performance active particles. Green Chemistry, 4. Retrieved from http:// pubs.rsc.org/en/content/articlelanding/2018/gc/c7g c02831h\#!divAbstract

Sivak, M. (2017). Has motorization in the U.S. peaked? Part 9: Vehicle ownership and distance driven, 1984-2015. (Report No. SWT-2017-4). Retrieved from http://umich.edu/ umtriswt/PDF/SWT-20174_Abstract_English.pdf

Smith, A. (2017). New 'trackless train' which runs on virtual rail lines launched in China. Metro. Retrieved from http://metro.co.uk/2017/10/28/new-tracklesstrain-which-runs-on-virtual-rail-lines-launched-inchina-7034155

Smith, G. (2017). Paris wants to ban the combustion engine by 2030 . Fortune. Retrieved from http:// fortune.com/2017/10/12/paris-combustion-engineban

Stone, J. (2014): Continuity and change in urban transport policy: Politics, institutions and actors in Melbourne and Vancouver since 1970. Planning Practice and Research, 29(4), 388-404.

Thomson, G., Newton, P., \& Newman, P. (2016). Urban regeneration and urban fabrics in Australian cities. Journal of Urban Regeneration and Renewal, 10(2), $1-22$.

Transport for NSW. (2017). Research and data: Transport performance and analytics (TPA). Transport for NSW. Retrieved from https://www.transport.nsw. gov.au/data-and-research

Transport for NSW. (2018). Driverless shuttle bus trial. Transport for NSW. Retrieved from https://www. transport.nsw.gov.au/data-and-research/researchhub/research-projects/driverless-shuttle-bus-trial

Travel China. (n.d.). Shanghai metro maps. Travel China Guide. Retrieved from https://www.travelchinaguide. com/cityguides/shanghai/transportation/metro-sub way-map.htm

Wavestone. (2017). World's best driverless metro lines: Wavestone transport and travel. Wavestone. Retrieved from https://www.wavestone.com/app/ uploads/2017/04/world-best-driverless-metro-lines2017.pdf

Wikimedia Commons. (2018). Rail passengers in Great Britain 1830-2015. Wikimedia. Retrieved from https://commons.wikimedia.org/wiki/File:GBR_rail_ passengers_by_year_1830-2015.png 


\section{About the Authors}

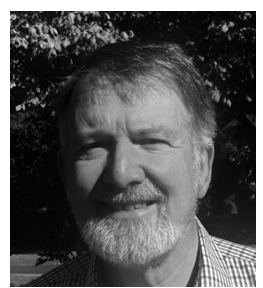

Garry Glazebrook (PhD) is an urban and transport planner with over 35 years' experience in government, consulting and academia. He has been involved in numerous consulting projects, particularly in public transport provision, and has worked for Federal, State and Local Governments in Australia. He has taught urban economics, sustainable transport planning and urban design at the University of Sydney's Urban Planning and other courses, and published extensively on urban transport planning and related topics.

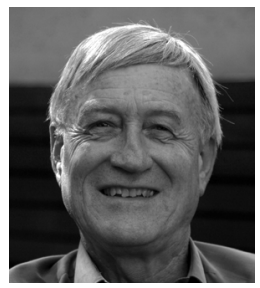

Peter Newman is the Professor of Sustainability at Curtin University in Perth, Australia. He has written 20 books and 340 papers on sustainable cities. Peter's book with Jeff Kenworthy Cities and Automobile Dependence (1989) has been described as "one of the most influential planning books of all time" by Reid Ewing Professor of City and Metropolitan Planning at the University of Utah. In 2014 he was awarded an Order of Australia for his contributions to urban design and sustainable transport. 